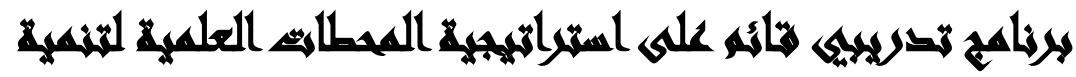

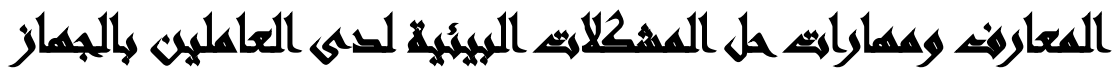

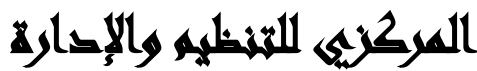

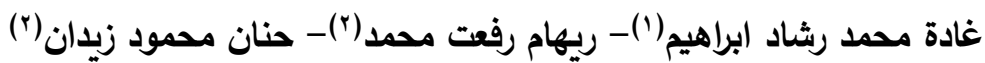

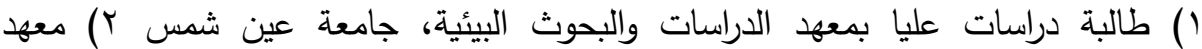

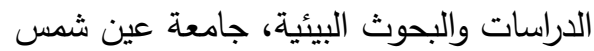

\section{المستخلم:}

هدف البحث إلى تتمية المعارف ومهارات حل المشكلات البيئية من خلال إعداد برنامج

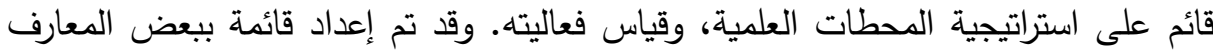

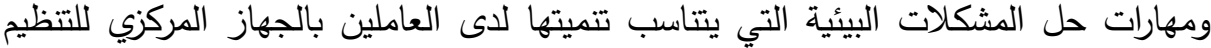

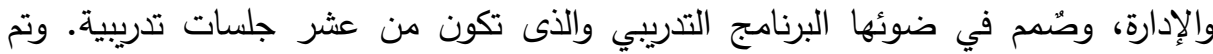

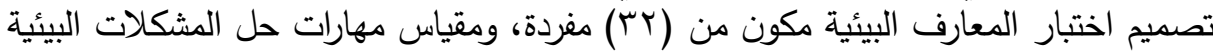

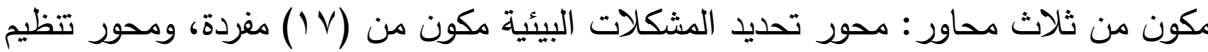

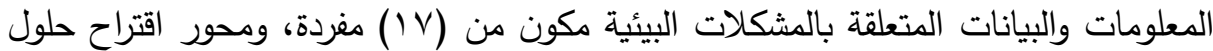

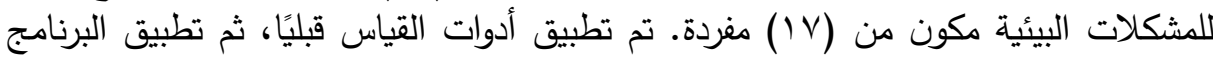

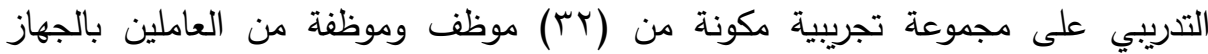
المركزي للتنظيم والإدارة، ثم تطبيق ادوات القياس بعديةًا.

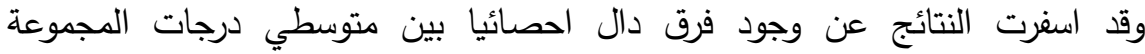

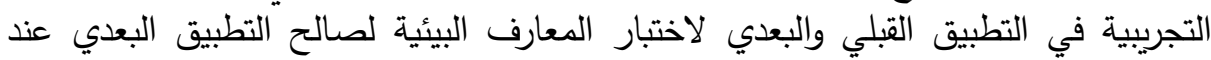

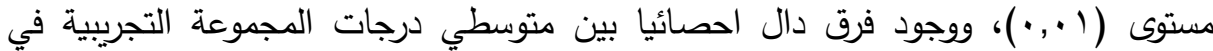

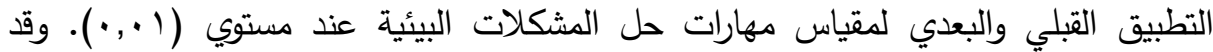
أوصى البحث بضرورة ضم البرنامج التدريبي إلى التى الخطة التدريبية المقدمة للعاملين بالجهاز 


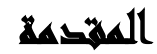

تعد البيئة ومشكلاتها، وعلاقة الإنسان بهما من القضايا المعاصرة الساخنة التي عرضت نفسها بإلحاح على الساحة الدولية؛ لذلك فعلى جميع المواطنين حول العالم بإختلاف ثقافتهم ومستواهم التعليمي والمعيشي وظروف حياتهم، الاهتمام بمعالجة هذه المشكلات فضلا عن المعنيين والمختصين بشئون البيئة ومشكلاتها، فتدهور العلاقة بين الإنسان والبيئة أدت إلى الى حدوث مشكلات بيئية خطيرة كإستتزاف مواردها وتلوثها، وباتت هذه المشكلات تهدد العناصر والكائنات والمخلوقات من حولنا، ويستوي في ذلك الدول المتقدمة والدول النامية لا فرق وناه بينهما.

وهدفت المؤتمرات والندوات العالمية التي شهدها العالم في الأعوام الماضية وما صاحبها من كتابات ومؤلفات؛ إلى تثخيص وتحليل ووضع حلول لتدهور عناصر البيئة الطبيعية

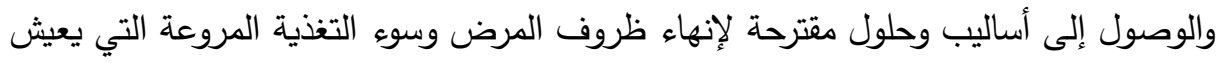

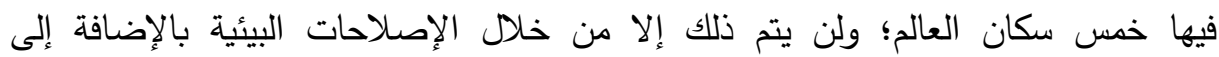
الإصلاحات الاقتصادية والإجتماعية، وتوضيح علاقة الارتباط بين التتمية الاقتصادية والتتمية

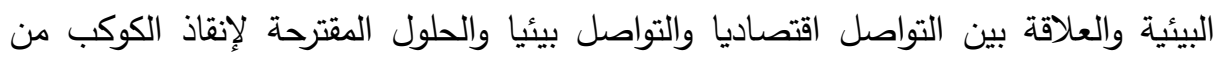
انهيار الإيكولوجية البيئية وبالتالي انهيار النظم الاقتصادية والاجتماعية. (نادية صالح، ولئه (r) , r...r ولجأت دول العالم لسن القوانين والتشريعات إزاء الخطر المتزايد للمشكلات البيئية والتي

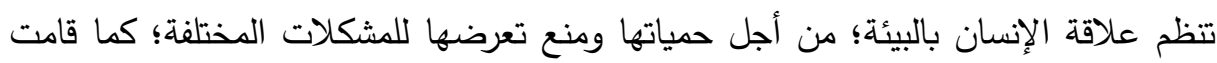
الدول بإجراء البحوث والدراسات للحد من تعرض البيئة لمشكلات اخري، ولقد علت التعند النداءات بضرورة وعي الإنسان بهذه المشكلات، وإدراك النتائج المترتبة عليها وتوفير احتياجاته بما لتصات يتماشى مع المحافظة على البيئة من حوله، وحثه على الاستهلاك المستدام، للحفاظ على حق ولى الإنى الأجيال القادمة في نصيبهم من الموارد الطبيعية اللازمة لإحتياجتهم المعيشية. 
ولكن هذه القوانين والتشريعات التي تتظم استغلال البيئة وتحافظ عليها، لم تستطيع وحدها صيانة البيئة ووقفت عاجزة، مالم يتحلى الإنسان بقدر كاف من الوعي بأهمية البيئة

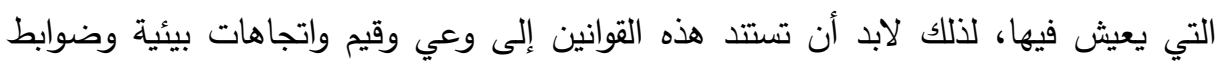

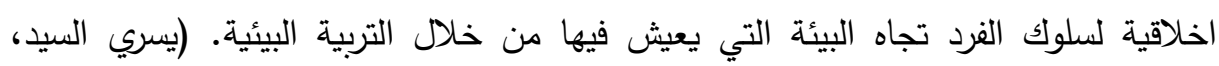

(YO ، Y . T T

ولقد استفاد الإنسان من تعامله مع البيئة واستغلال مواردها الطبيعية، فأصبح يخطط لإقامة المشاريع التتموية دون الحاق الاذي والدمار في بيئته، وذلك من خلاد العانية العلاقة القوية بينهما عن طريق التربية البيئية التي تؤدي الى تتمية معارف واتجاهات الإنسان عن البيئة، وزيادة وعيه وتعديل اتجاهاته وسلوكه نحوها، وتتشئة مواطنين يدركون أبعاد مشكلات البيئة

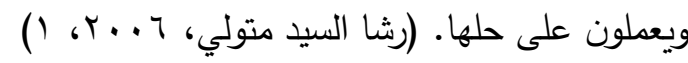

ذلك لان المشكلات البيئية الكبرى التي تعاني منها البشرية حاليا تعود إلى الإنسان نفسه

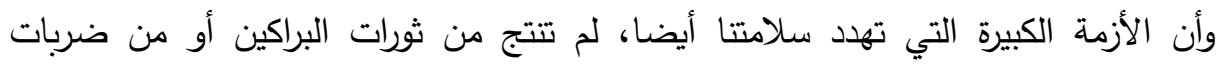

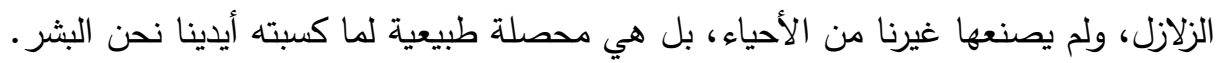

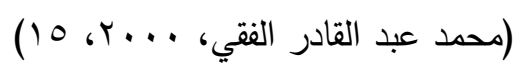

ويجب لحل المشكلات البيئية أن تتوافر مجموعة من المهارات التي تتطلب من المتعلم معرفتها حتى نستطيع أن نقول ان المتعلم قد توصل إلى حقائق ومعارف بيئية أدت إلى تكوين الجوانب الوجدانية والمهارية لدى الفرد، وتتمثل هذه المهارات في تحديد المشكلة التي تعاني

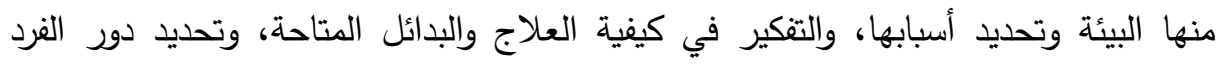

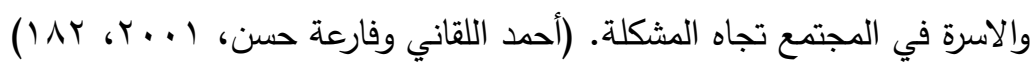

\section{And}

شعر الباحثون بمشكلة البحث من خلال عمل إحداهن بالجهاز المركزي للتظيم والإدارة،

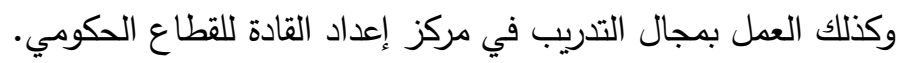

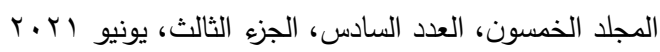

$$
\begin{aligned}
& \text { الترقيم الدولي 0826- التئي }
\end{aligned}
$$


وقد تم تحديد أبعاد هذه المشكلة وأهمية التصدي لها من خلال ما يأتي:

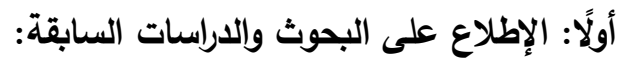

في مجال المعارف البيئية: أثارت العديد من الدراسات مثل دراسة (يحي الثيباني، ع . . ب)

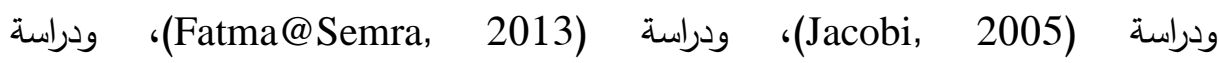
( Skoumios, 2013 Hadzigeorgiou)

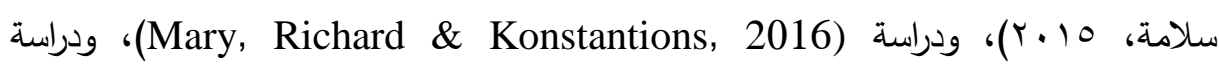

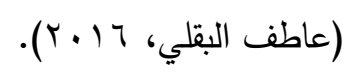

في مجال مهارات حل المشكلات البيئية: أشارت العديد من الدراسات مثل دراسة

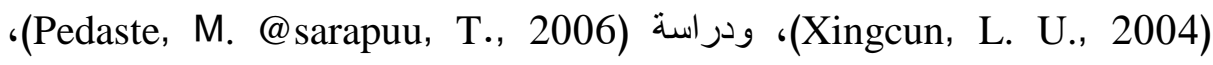

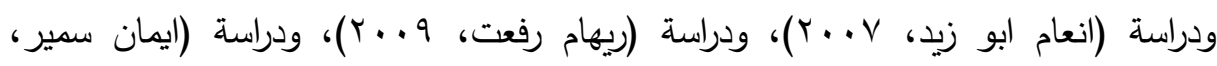

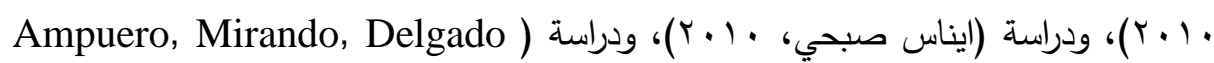

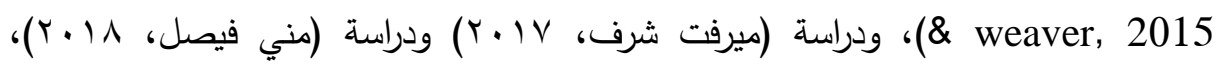

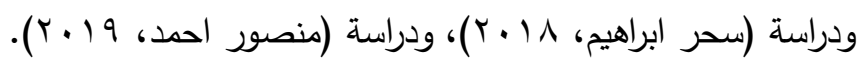
في مجال استراتيحية المحطات العلمية: أثارت العديد من الدراسات مثل دراسة، ودراته

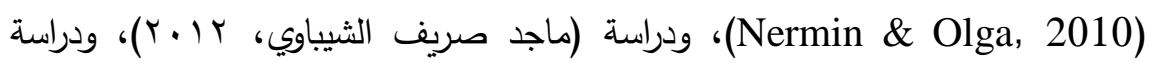

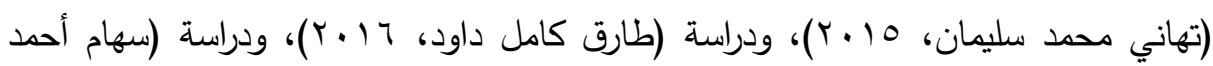

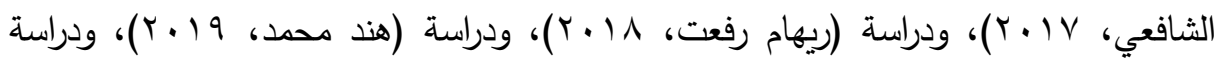

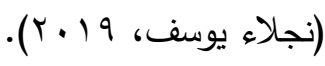
في مجال البرامج التدريبية المرتبطة بالبيئة: أشارت العديد من الدراسات مثل دراسة (هبة الله

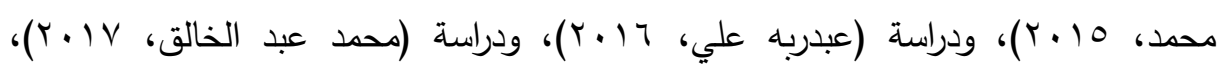

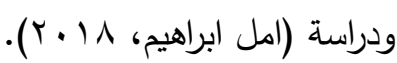

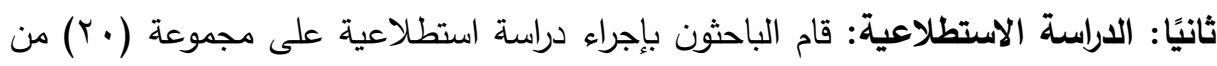

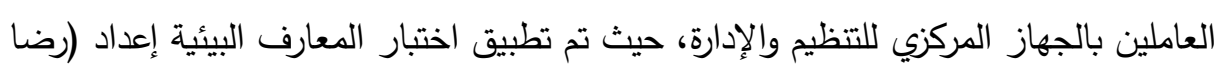
248

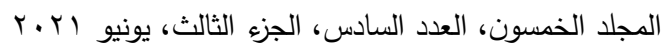

$$
\begin{aligned}
& \text { الترقيم الدولي 0826- ISSN 1110 }
\end{aligned}
$$




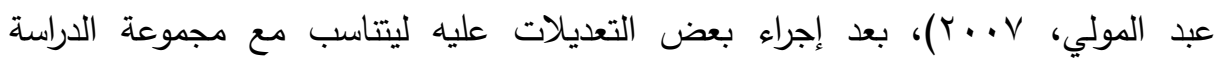

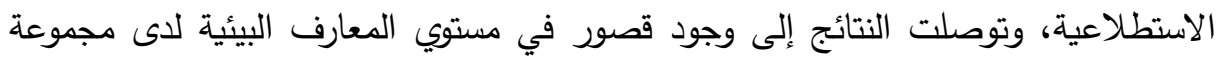

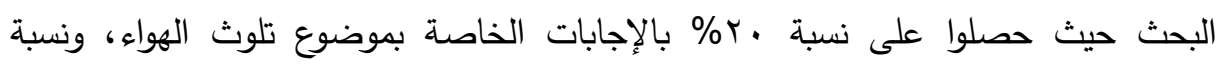

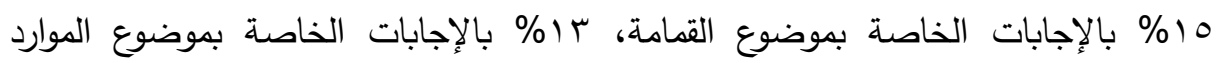

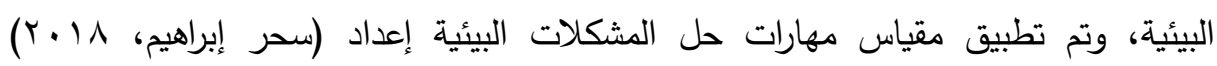
وتوصلت النتائج إلى وجود قصور في مستوي مهارات حل المشكلات البيئية لدى مجموعة إلى البهات البحث، حيث حصلوا على نسب · (\% بالإجابات الخاصة بمهارة تحديد المشكلة البيئية،

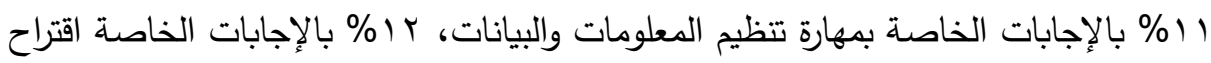
حلول بديلة للمشكلات. وتحددت مشكلة البحث في وجود قصور وضعف في مستوي المعارف ومهارات حل بل المشكلات البيئية لدى العاملين بالجهاز المركزي للتنظيم والإدارة ببعض القضايا البيئية، وضرورة استخدام استراتيجيات تدريبية متنوعة لتتمية تلك المعارف ومهارات حل المشكلات

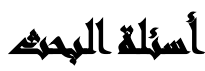

تم صياغة مشكلة البحث في السؤال الرئيسي التالي: "ما فاعلية برنامج تدريبي قائم على التى استراتيجية المحطات العلمية لتمية المعارف ومهارات حل المشكلات البيئية لدى العاملين بالجهاز المركزي للتظيم والإدارة؟" ويتفرع عن هذا السؤال الأسئلة التالية:

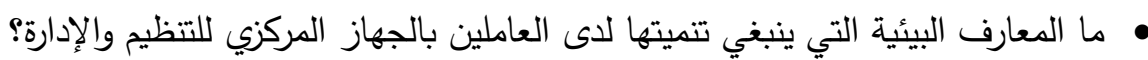

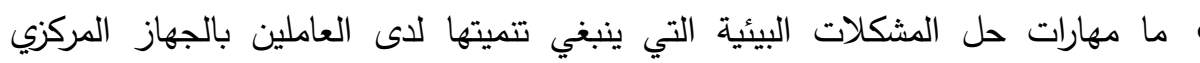
للتنظيم والإدارة؟ هات ما التصور المقترح للبرنامج التدريبي القائم على استراتيجية المحطات العلمية لتتمية المعارف ومهارات حل المشكلات البيئية لدى العاملين بالجهاز المركزي للتظيم والإدارة؟ 
• ما فاعلية البرنامج التدريبي القائم على استراتيجية المحطات العلمية في تتمية المعارف

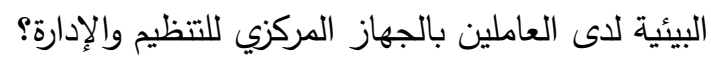

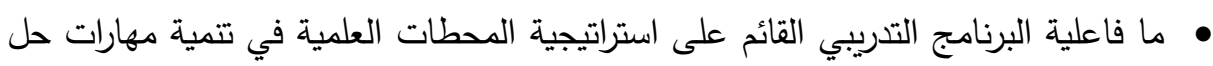
المشكلات البيئية لاى العاملين بالجهاز المركزي للتنظيم والإدارة؟

\section{هروغ المهيث}

1-يوجد فرق دال إحصائيا بين متوسطي درجات متدربين المجموعة التجريبية في اختبار المعارف البيئية قبل تطبيق البرنامج التدريبي وبعده لصالح التطبيق البعدي.

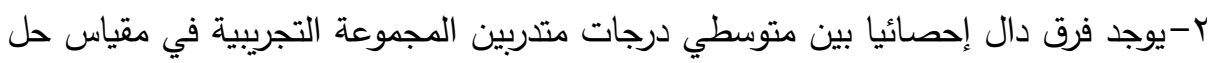
المشكلات البيئية قبل تطبيق البرنامج التدريبي وبعده لصالح التطبيق البعدي.

\section{أهمانهت الهمبه}

استهدف البحث الحالي: تنمية المعارف ومهارات حل المشكلات البيئية للعاملين بالجهاز المركزي للتظيم والإدارة من خلال تطبيق البرنامج التدرببي القائم على استراتيجية المحطات العلمية.

\section{أهمية الهيهم:}

الاهمية النظرية: تتمثل الاهمية النظرية للبحث في تقديم:

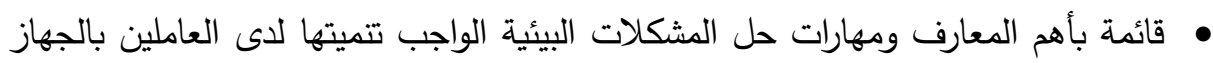

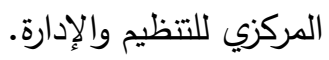
• ادوات لقياس المعارف البيئية ومهارات حل المشكلات البيئية لاى العاملين بالجهاز المركزي للتنظيم والإدارة. • برنامج تدريبي قائم على استراتيجية "الدحطات العلمية". 
الاهمية التطبيقية: قد يستفيد من البحث الحالي الفئات التالية:

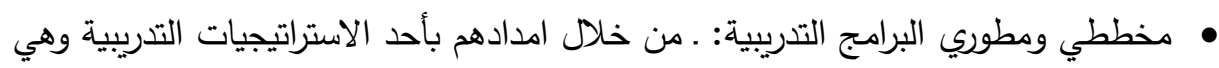

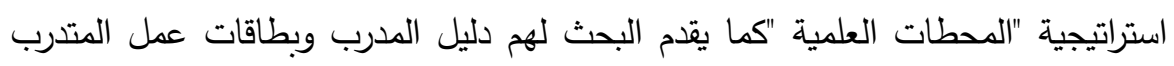
الذي يشتمل على تخطيط الجلسات التدريبية المبنية على الإطار النظري للدراسة، وفقا لاستراتيجية المحطات العلمية.

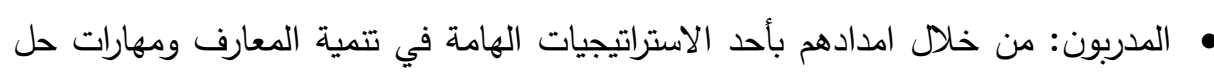
المشكلات البيئية وهي استراتيجية المحطات العلمية. • المتدربون: من خلال تتمية المعارف ومهارات حل المشكلات البيئية لادهم عن طريق لعني تعرضهم للبرنامج التدريبي.

\section{Aatl}

الحدود البشرية: تم تطبيق البحث على مجموعة من العاملين بالإدارة المركزية (مركز إعداد

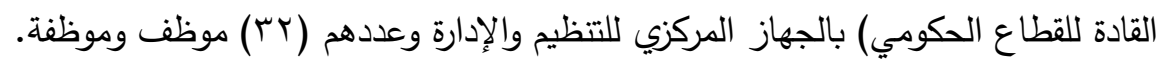

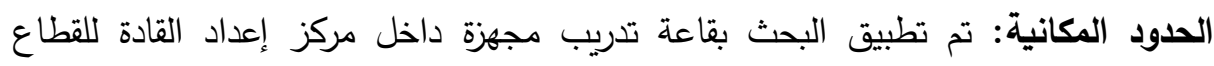
الحكومي. الحدود الزمنية: تم تطبيق البحث خلال شهر فبرايرفي النصف الثاني من العام التدريبي . r. Y Y / r. r.

\section{أسواهت اللهمثي}

$$
\text { • مقياس حل المشكلات البيئية. (إعداد الباحثون) البياد البادئية) }
$$

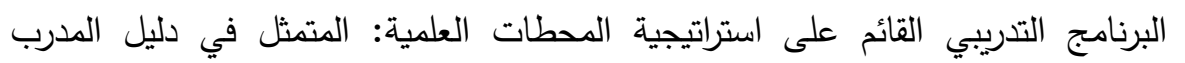
وبطاقات عمل المتدرب لتدريس البرنامج التدريبي وفق استراتيجية المحطات العلمية.

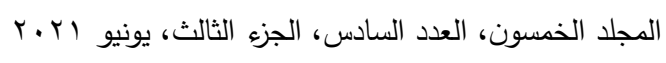

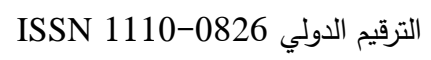




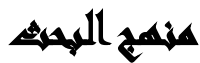

استخدم البحث المنهج التجريبي (بإجراءاته شبه التجريبية): لتجريب استخدام البرنامج التدريبي، وقياس فعاليته في تتمية مستوى المعارف ومهارات حل المشكلات البيئية للى الدي العاملين بمركز إعداد القادة للقطاع الحكومي بالجهاز المركزي للتظيم والإدارة، فالتصميم شبه التجريبي الذي يتبعه البحث هو التصميم القائم على مجموعة تجريبية واحدة وذلك لأنه الانسب للتعامل مع متغيرات البحث، كما أنه قائم على استراتيجية محددة وهي استراتيجية المحطات العلمية.

\section{هصطالماهد البهيف}

برنامج تدريبي: Training program مجموعة من الخبرات والأنشطة والاساليب التعليمية المختلفة التي تتضمنها خطة تعليمية منظمة، بهدف تحقيق تغييرات مرغوبة في كافة الجوانب

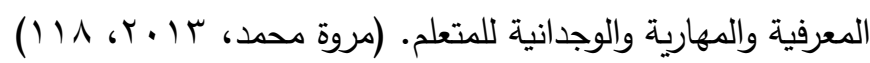
استراتيجية المحطات العلمية: Scientific Stations Strategy طريقة تدريس ينتقل فيها الطلاب في مجموعات صغيرة عبر سلسلة من المحطات مما يتيح للمتعمين تأدية كل

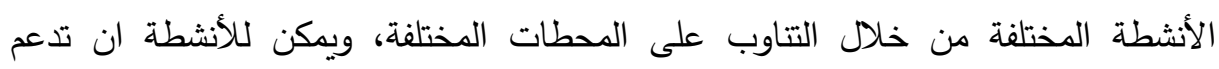
تدريس المفاهيم التي تحتاج إلى قدر كبير من التكرار والمفهوم الواحد أوعده مفاهيم. (Jones, 2007,99: 100)

المعارف البيئية: Environmental Knowledge المعرفة البيئية هي حصيلة المعلومات

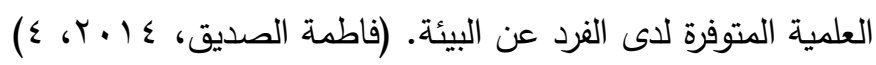
مهارة حل المشكلات البيئية: Skill Solving Environmental Problem يقصد بمهارة حل المشكلات البيئية قدرة الفرد على إدراك وتحديد وتنظيم وتحليل المعلومات واقترح الحلول البديلة ووضع خطة عمل لحل المشكلات البيئية (Xingcun, L. U., 2004)

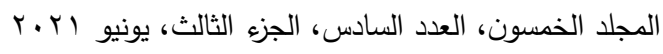

$$
\begin{aligned}
& \text { الترقيم الدولي 0826-0 التئي }
\end{aligned}
$$




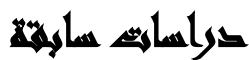

دراسات تناولت استراتيجية المحطات العلمية:

دراسة (Marvin, 2007): هدفت إلى معرفة أثر استراتيجية المحطات العلمية في تدريس اللغة الإنكليزية لتحسين نقاط الضعف لدى الطلاب والسماح لهم بالمشاركة والانخراط في العملية التعليمية، وتوصلت النتائج إلى فعالية استراتيجية المحطات العلمية في تدريس اللغة

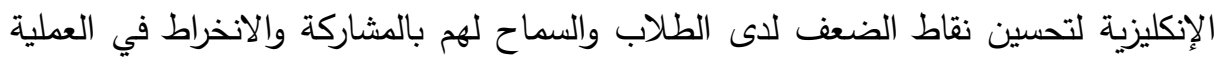
التعليمية لدى أفراد العينة.

دراسة (Ocak, 2010): هدفت إلى معرفة فاعلية استخدام استراتيجية المحطات العلمية في

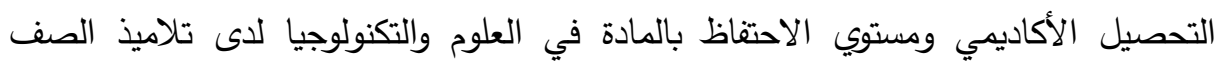
الخامس الابتدائي بإحدى المدارس التركية، وتم اختيار فصلين، ثم تحديد أحد الفصلين تالين كمجموعة تجريبية والفصل الاخر كمجموعة ضابطة، وتم استخدام أدوات القياس قبلياً وبعديا، وتوصلت النتائج إلى فاعلية استخدام محطات التعلم في التحصيل الأكاديمي ومستوي الاحتفاظ بالمادة في العلوم والتكنولوجيا لاى تلاميذ الصف الخامس الابتدائي.

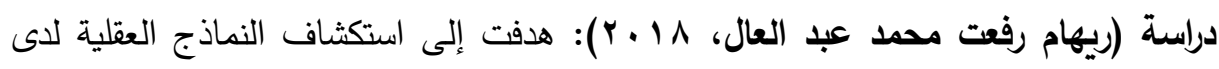
طالبات الصف الأول الثانوي وتصور مقترح لتطويرها في ضوه استراتيجية المحطات التعليمية، وتوصلت الدراسة إلى ان طالبات الصف الأول الثانوي لا يقدمن الا وصفاً سطحياً ورؤية بيئية قاصرة، وأنهن قمن ببناء نماذجهن من خلال إدراك البيئة كوحدة للأنظمة بل البل

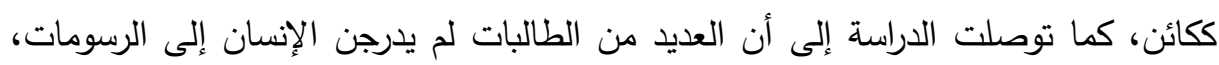
كما أنهن يرسمن العوامل الحية بدون إدراج العناصر الأخرى. دراسات تناولت المعارف البيئية:

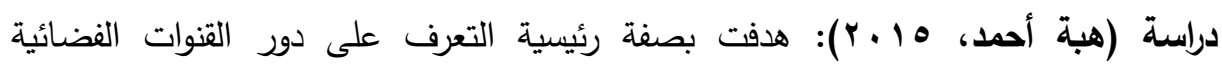
الزراعية في تتمية المعارف والمهارات البيئية وسبل العيش لدى مزارعي محافظة شمال سيناء

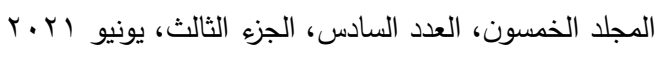

$$
\begin{aligned}
& \text { الترقيم الدولي 0826- ISSN 1110 }
\end{aligned}
$$


وقدمت الدراسة مجموعة من التوصيات التي قد تقيد في تتمية المعارف والمهارات البيئية وسبل العيش بمنطقة الدراسة. دراسة (عاطف البقلي، 17 + ب): هدفت إلى بناء برنامج مقترح لتمية المعارف والمهارات

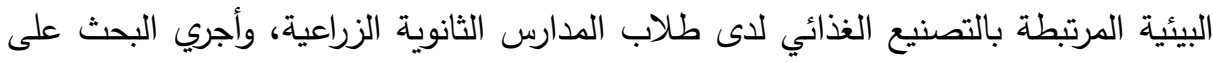
. . . . ل

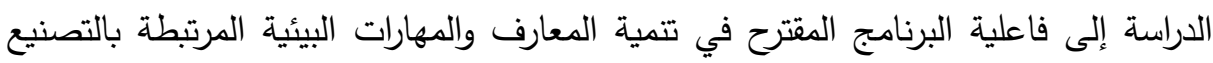

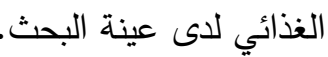
دراسات تناولت مهارات حل المشكلات البيئية: دراسة (Ampuero, Mirando, Delgado \& weaver, 2015): هدفت الى التعرف على فاعلية الأنثطة البيئية القائمة على مدخل النظم في تتمية مهارات حل المشكلات البيئية

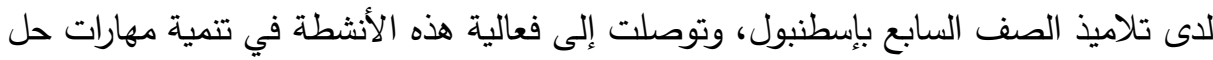
المشكلات البيئية لدى تلاميذ العينة.

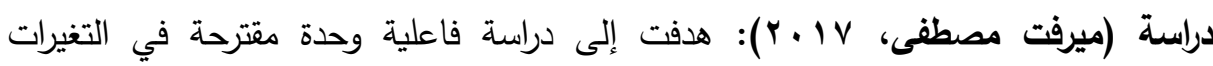
المناخية قائمة على مدخل الدراسات البيئية في تتمية التحصيل ومهارات حل المشكلات في مادة العلوم لدى تلاميذ الصف الثاني الإعدادي، وتوصلت إلى فاعلية هذه الوحدة المقترحة في تتمية التحصيل ومهارات حل المشكلات لاى عينة البحث. دراسات تناولت البرامج التدريبية في مجال البيئية:

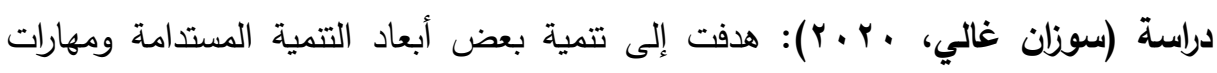

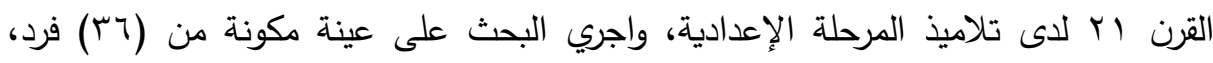
وتوصلت الدراسة إلى وجود فرق دال احصائيا بين متوسطى درجات مجموعة الدراسة في

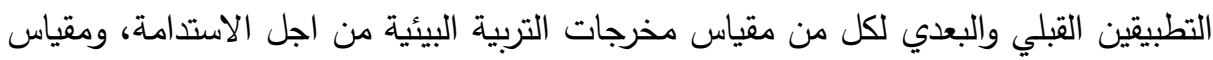
مهارات القرن اب لصالح التطبيق البعدي مما يدل على فاعلية البرنامج المقترح. 


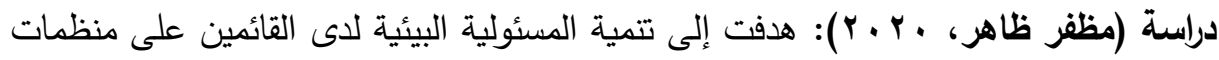
المجتمع المدنى وأثره على الاعضاء من خلال برنامج مقترح عن جودة الحياة، وتوصلت نتائج

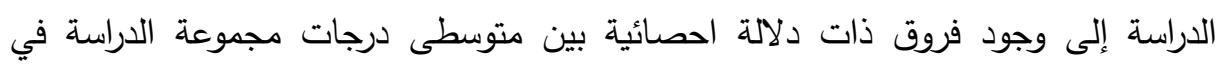

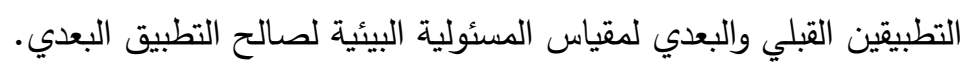

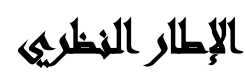

مفهوم استراتيجية المحطات العلمية: تعرف بأنها مناطق مخصصة في القاعات الدراسية

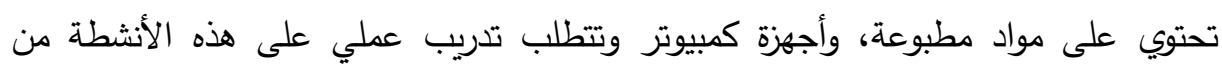
خلال تقسيم المتعلمين إلى مجموعات صغيرة تدور على هذه واد المناطق المختلفة لمناقشة موضوع معين. (Chamber, 2013, 15)

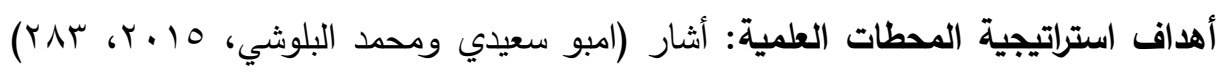
أن لإستراتيجية المحطات العلمية العديد من الأهداف ومنها:

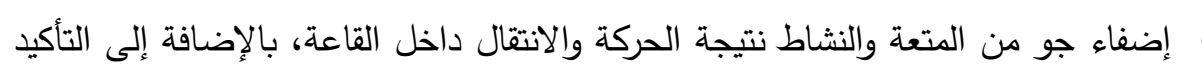

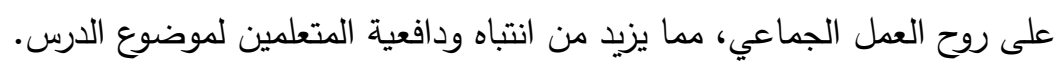

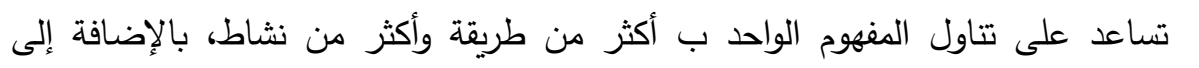
تدريس كمًا كبيرا من المفاهيم العلمية الاساسية للمتعلمين في فترة زمنية قصيرة.

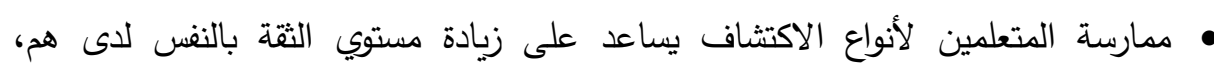
وقدرتهم على الحصول على المعلومات واكتشافها بأنفسه وهذا يؤكد على المنحي البنائي في الحصول على المعرفة. ه امكانية الاستفادة من الموارد المتاحة كالكتب وأجهزة المعامل، والوسائل التعليمية، وأجهزة

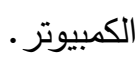
ت تساعد في تتمية مهارات عمليات العلم الاساسية لاى المتعلمين، حيث يمارسون عمليات الملاحظة، الاتصال، التتبؤ وبالتالي تقدير دور العلم والعلماء. 
• تعمل على زيادة جودة المواد التعليمية المعروضة من خلال العينات الحية أو الصور المكبرة والملونة، حيث يتم وضعها في محطة واحدة يمر عليها كل مجموعة.

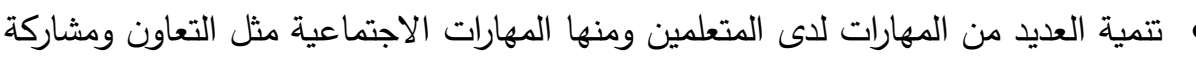
الاخرين وتقبل الرأي الاخر وغيرها. • تحيق إدارة فعالة داخل قاعة التدريب حيث سينخرط المشاركين في أنشطة وأعمال مختلفة.

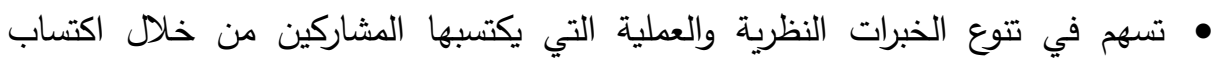
المفاهيم العلمية المجردة بنفسه عن طريق الملاحظة والتجريب. ه استخدام المصادر العلمية الاصيلة كالموسوعات والاطالس وغيرها حيث يتم وضعها في

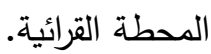

بقاء أثر التعلم نتيجة مرور المتعمين بخبرات حسية واكتسابهم المعلومات من خلال الاستقصاء.

• التغلب على نقص الموارد وقلة الادوات والامكانات المتاحة لممارسة الأنثطة التعليمية حيث يتم استخدام الادوات الازمة لتنفيذ النشاط أكثر من مرة من خلال مرور كل مجموعة الدوات علية، وبالتالي ليس من الضروري توفير مواد وادوات لكل افراد المجموعة.

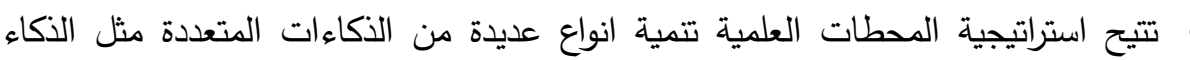
الاجتماعي والمنطقي الرياضي والبصري والحركي واللغوي..... وغيرها.

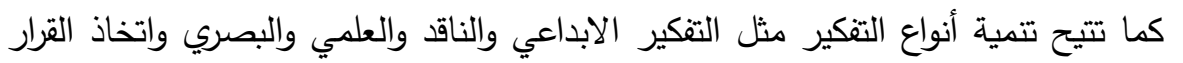
وغيرها.

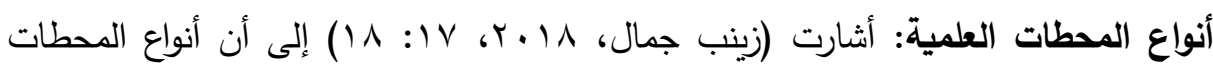
العلمية تتمثل فيما يلي: • المحطة الاستقصائية (الإستكثافية): تختص هذه المحطة بالأنشطة العلمية، مثل اجراء تجربة معينة في وقت قصير، ثم الإجابة عن عدد من الأسئلة المرتبطة بهذه التجربة. 


$$
\begin{aligned}
& \text { مجلة العلوم البيئية } \\
& \text { معهد الدراسات والبحوث البيئية - جامعة عين شمس لئه } \\
& \text { غادة محمد رشاد وآخرون }
\end{aligned}
$$

• المحطة القرائية: تتطلب هذه المحطة وجود مادة قرائية مثل مقال من صحيفة أو كتاب أو موسوعة علمية أو نشرة علمية... الخ، وتقوم كل مجموعة بقراءة المادة المعروضة في هذه هنه المحطة، ثم الإجابة عن الأسئلة الموجودة بها.

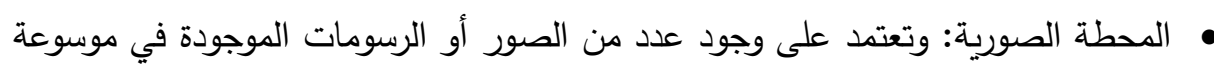

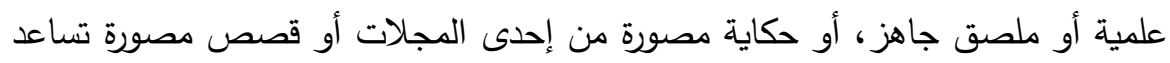

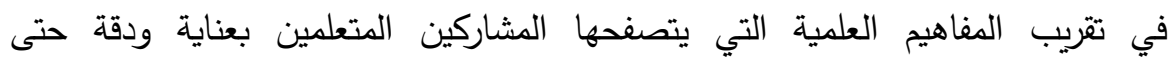
يستطيعون الاجابة على الأسئلة الموجودة بهذه المحطة.

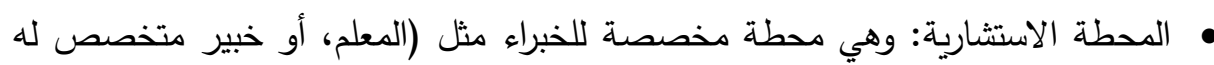
علاقة بالموضوع المطروح، أو أحد الطلبة المتفوقين)، وعند وصول كل مجموعة لهذه

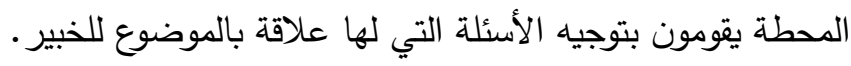
هالمطة السمعية/البصرية: يتم وضع جهاز تسجيل أو فيديو لمشاهدة فيلم تعليمي لله علاقة بالموضوع المطروح، ويقوم المشتركين بالاستماع أو مشاهدة المادة العلمية المعروضة، ثم يجيبون على عن الأسئلة المحددة بأوراق العمل. هالمطة الالكترونية: تعتمد على وجود جهاز حاسوب، حيث تقوم كل مجموعة بمشاهدة المبه عرض تقديمي على البوربوينت أو البحث في الانترنت أو تقديم أفلام تعليمية لها علاقة بالموضوع المطروح، ثم الاجابة عن الأسئلة الموجودة بهذه المحطة.

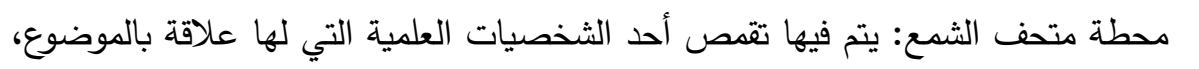

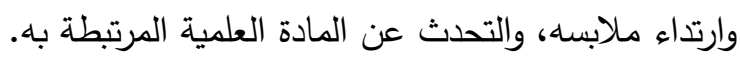
محطة النعم والـ لا: يتم طرح مجموعة من الأسئلة من قبل المشاركين على المعلم أو أوند الخبير الموجود بهذه المحطة وذلك للحصول على اجابات بنعم أو لا دون الدخول في لتي تفاصيل.

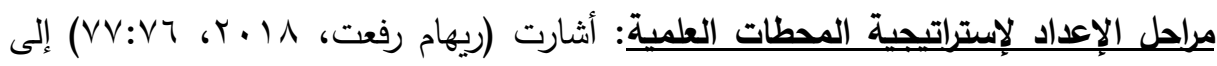
أن مراحل الإعداد لإستراتيجية المحطات العلمية كالتالي:

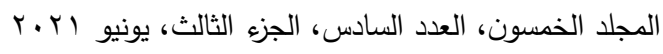

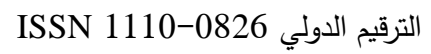


1-عرض مقدمة عن موضوع المحاضرة ة، وتعريف المجموعات المطلوب القيام به عند التجوال على محطات التعلم. ץ-تثكيل مجموعات غير متجانسة من المتعلمين ما بين (؟-^) متعلم.

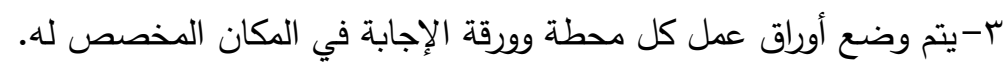
ع-يتم الاعلان عن بدء تتفيذ أوراق عمل المحطات والاعلان عن الوقت المحدد للمكوث في كل محطة.

ه-بعد انتهاء الوقت المحدد تقوم المجموعات بالإنتقال إلى المحطة التالية.

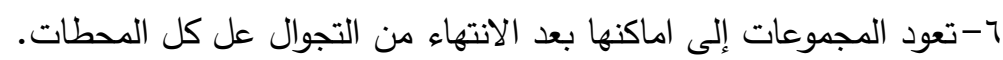
V - البدء في مناقثة ما توصلت اليه كل مجموعة. ^-يتسلم المعلم أوراق الاجابة من المجموعات ويقوم بتصحيحها واعاداتها لهم في المحاضرة التالية وتقديم التغذية الراجعة.

المعارف البيئية: تعريف مؤتمر تيبلسي للمعارف البيئية عام 9VV اوالذي اعتبره هدفا من أهداف التربية البيئية انه معاونة الأفراد والجماعات على اكتساب خبرات متنوعة وفهم البيئة

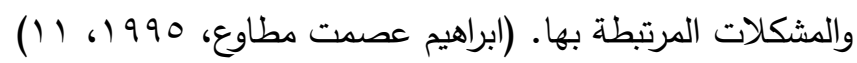
وتعرف أنها: مساعدة الأفراد للحصول على تجارب متتوعة في البيئة، واكتساب الفهم

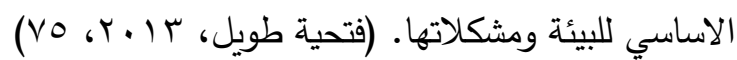
وتتكون المعارف البيئية من خلال: • معلومات مستوحاة عن البيئة: من خلال القواعد والمبادئ لجوانب المعرفة العلمية، والتي يستخدمها الفرد لتفسير الظواهر البيئية والعلاقات القائمة بين الاشياء الحية وغير الحية وأثر الإنسان على بيئته وكيف يتعامل معها.

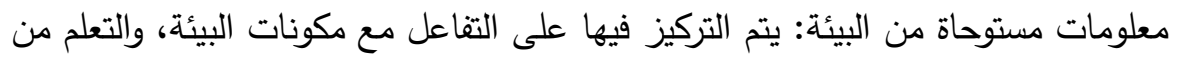
البيئة من خلال الرحلات والزيارات التي يقوم بها الفرد، ويتم تعلم المعارف بالمشاهدة 
• معلومات مستوحاة من اجل البيئة: وتهدف إلى المحافظة على البيئة وحسن استثمارها والاستمتاع بها، ويتم تحديد ممارسات الإنسان الخاطئة والسليمة والاستفادة من البيئة

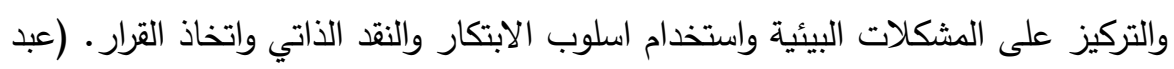

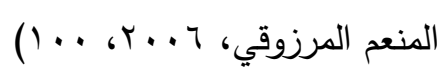

فالمعرفة البيئية يترتب عليها فهم المشكلات البيئية، والاحساس بالمسئولية، ثم المشاركة

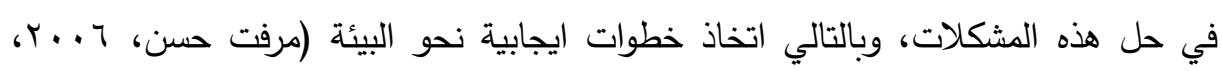
هو OV

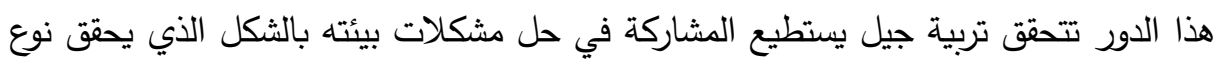

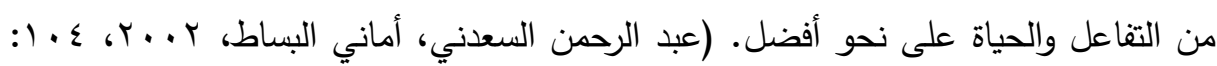

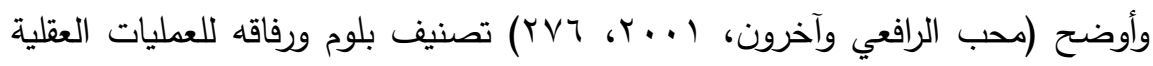

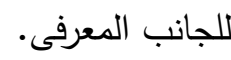
1-التذكر: التي تثتمل على الإسترجاع وتدور حول معرفة الحقائق والبيانات والمعلومات، والعلاقة المتبادلة بين الإنسان والبيئة. r-الفهم: يتمثل في تفسير الأفكار المكتسبة من القراءة والاطلاع والثرح والمناقشة.

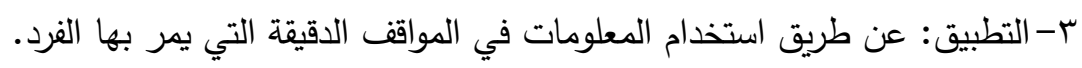
ع - التحليل: اكتثاف المعني العميق والتميز بين الجوهر والعرض. 0- التركيب: تجميع الجزئيات الاساسية في معني جديد وابتكار افكار جديدة. צ-التقويم: إصدار احكام على الموقف التعليمي من خلال اكتساب المتعلم سمات مديزة للثخصية.

ولما كان أحد أهداف التربية البيئية: اكساب الفرد المعارف والمفاهيم البيئية وزيادة الوعى المئي والمسؤولية والإدراك نحو القضايا البيئية، وجب على البحث الحالي التطرق الى المفاهيم البيئية بإعتبارها أهم مكون من مكونات المعارف البيئية. 
المفهوم البيئي هو: صورة ذهنية مجردة يعبر عنها بكلمة أو تركيب بسيط ذو دلاله لفظية

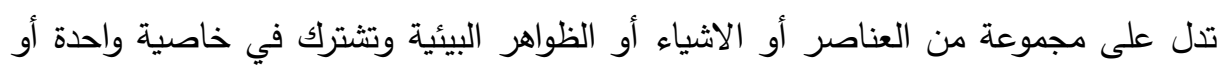

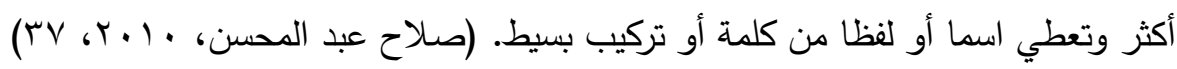

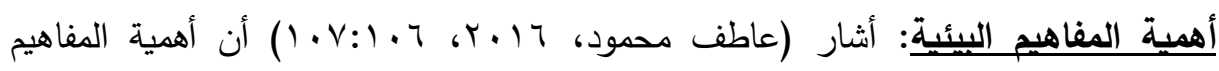
البيئية تتلخص في: المفئ • يساعد المفهوم على فهم الكثير من المعلومات في المراحل التعليمية التالية وانتقال أثر التعلم.

• يعتبر المفهوم مدخلا هاما من مداخل تكامل الحقائق والبيئة مع المواد التعليمية، وتربط بين الكثير من الحقائق وادارك العلاقات بينهما.

• يعد تعلم المفاهيم البيئية ضرورة لتفسير المشكلات التي تواجاه الفرد واقتراح حلول لها. يساعد المفهوم على تسهيل دراسة مكونات وظواهر البيئة، في مجموعات. يساعد وجود اساس من المفاهيم على تحقيق أهداف التربية البيئية، وفهم المبادئ والقوانين والنظريات. تساعد المفاهيم البيئية على زيادة قدرة المتعلم على استخدام وظائف العلم الرئيسية من تقسير وتحليل وتتبؤ.

مهارات حل المشكلات البيئية: تعرف بأنها: عدد من المهارات الازمة لحل المشكلات البيئية وهي كالأتي: تحديد المشكلات البيئية، جمع المعلومات المتصلة بالمشكلات البيئية، اقتراح الحلول للمشكلات البيئية، اختيار الحلول المقترحة، تقسير المشكلات البيئية، تعميم النتائج.

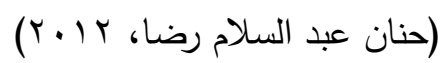

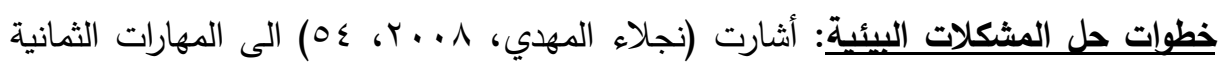
التي حددها (ستاب وكوكس) في حل المشكلات البيئية كالأتي:

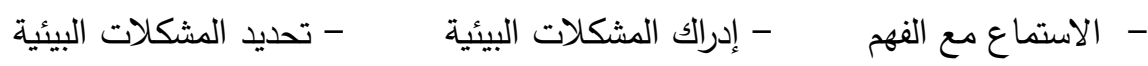

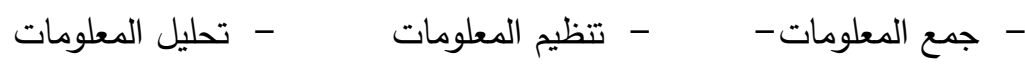




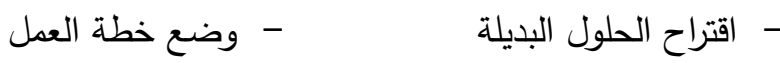

ووضعت البنود السابقة في ثلاث مجموعات تمثل مهارات حل المشكلات البيئية وذلك

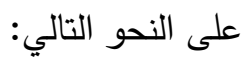
- - - إدرالك وتحديد المشكلات البيئية.

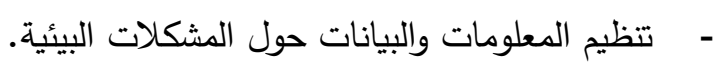
- - اقتراح الحلول البديلة للمشكلات البيئية.

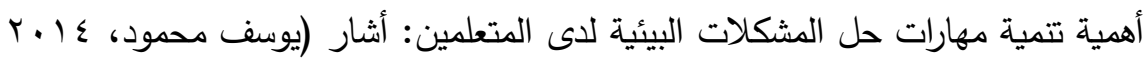

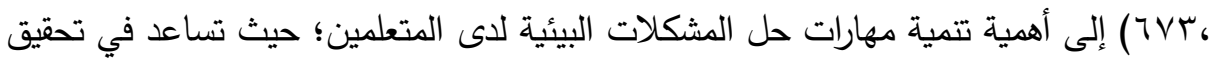
العديد من الفوائد منها: - تقديم المعرفة في صورة مشكلات تحفز المتعلم على إعمال عقله للوصول إلى حل لها من خلال اختيار الحلول المناسبة من ضمن البدائل المطروحة لحلها بالإضافة إلى استخدام الخبرات التي مر بها المتعلم وتفاعل معها.

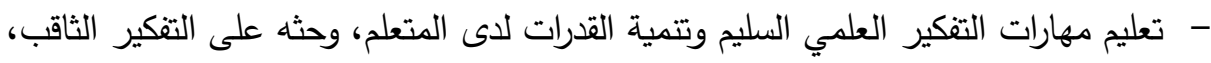
حيث أن كل خطوة أو مرحلة فيها تعتبر مهارة عقلية بسيطة وبمجموعها يكتسب المتعلم مهارة حل المشكلة.

- مساعدة المتعلمين على تتمية التفكير الابداعي والتفكير الناقد. - مساعدة المتعلمين على التكيف في حياتهم واتخاذ القرارت السليمة لكثير من المواقف التي التيل تواجههم في الحياة اليومية، عندما يوضع المتعلم امام مشكلة حقيقة، وتدريبه على الوصول إلى حلول، تجعلهم في كل خطوة يصنعون قرارا. - تزويد المتعلمين بأطر عمل منظمة لتحليل تفكيرهم في مواقف غئفون فران فير تقليدية لحل المشكلات. - تمكين المتعلم من معالجة وتخزين المعلومات، وتطبيقها في مواقف جديدة غير مألوفة، وذلك من خلال تدريهم على استخدام مهارات اكتساب المعلومات بدلا من الحصول عليها 
جاهزة، وتزويدهم بمهارات التحليل والاستقصاء واصدار القرارات وتطبيقها في حل

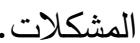

البرنامج التدربي: خطة تعليمية تتضمن مجموعة من الأهداف التدريبية المراد تحقيقها في ضوء تحليل العمل والمحتوى واساليب التدريب والوسائل المساعدة بالإضافة إلى ادوات للتقويم،

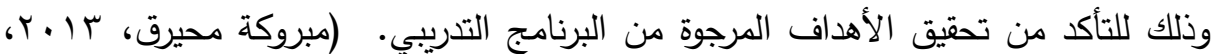

الاعتبارات الواجب مراعاتها في تصميم البرامج التدريبية: أشارت (هالة عادل، ع ( ب، ع ( ) أن هنالك عدد من الاعتبارات الواجب مراعاتها في تصميم البرامج التدريبية. 1-تحديد المعلومات الأساسية، وربط المعلومات الجديدة بالسابقة. r-مناقثة وجهات نظر المتدربين وتوضيح القيم، الفوائد، والاتجاهات. r-تشجيع المتدربين على المشاركة الفعالة، والتحفيز على الابداع. ع-ربط محتوي البرنامج التدريبي بالاحتياجات التدريبية للمتدربين. 0- الاستفادة من الوسائل والمعينات التدريبية المتاحة. ج-ربط المحتوي التدريبي ببيئة العمل.

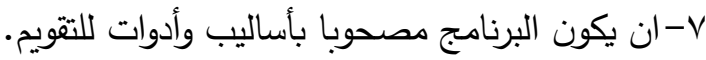

فالبرامج التدريبية في مجال البيئة يجب أن تقدم محتوي للمتدربين يسهم في المشاركة الفعالة في معالجة القضايا البيئية وتطوير ظروف البيئة على نحو أفضل ومنع حدوث مشاكل جديدة، فالحفاظ على البيئة والمساهمة في حل مشكلاتها مرهون بدرجة معارف ومهارات الفرد ولئه وقيمه والتزامه بأخلاقيات التعامل مع البيئة واحترام قوانينها والدفاع عن قضاياها، وحماية

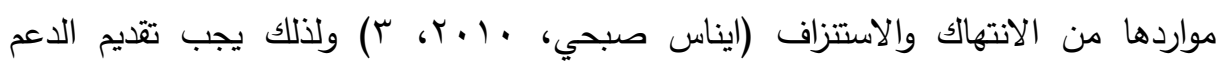
والتدريب للمواطن لإعداده للمساهمة في تحقيق خطط التتمية المستدامة والحفاظ على التوازن 


\section{إلجراعاهي اللهمشه}

للإجابة عن السؤالين الأول والثاني للبحث:

• ما المعارف البيئية التي ينبغي تتميتها لاى العاملين بالجهاز المركزي للتنظيم والإدارة؟

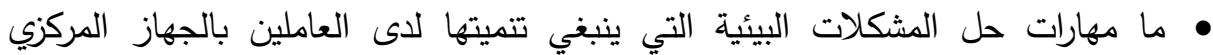

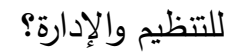

تم اتخاذ الإجراءات التالية: إعداد قائمة القضايا والمشكلات البيئية لتمية المعارف ومهارات حل المشكلات البيئية لاى العاملين بالجهاز المركزي للتظيم والإدارة.

الهرف من إعداد القائمة:

• تحديد المعارف البيئية المراد تتميتها لدى العاملين بالجهاز المركزي للتظيم والإدارة. • تحديد مهارات حل المشكلات البيئية المراد تتميتها لاى العاملين بالجهاز المركزي للتنظيم

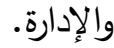

• تصميم المحتوي العلمي للبرنامج التدريبي القائم على استراتيجية المحطات العلمية في ضوء القضايا والمشكلات البيئية المختارة. • • بناء الاختبار التحصيلي الخاص بالمعارف البيئية المراد تتميتها. • بناء مقياس حل المشكلات البيئية للقضايا والمشكلات البيئية المختارة.

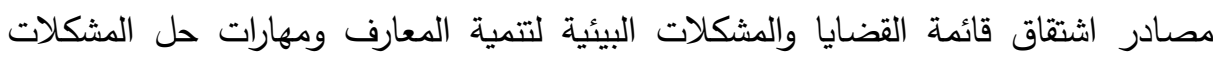
البيئية لاى العاملين بالجهاز المركزي للتتظيم والإدارة. • البحوث والدراسات السابقة العربية والاجنبية في مجال البحث العلمي والكتب والمراجع:

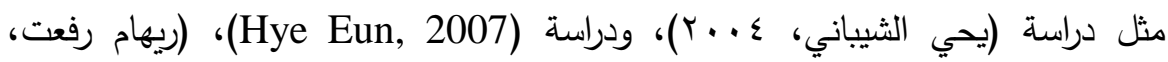

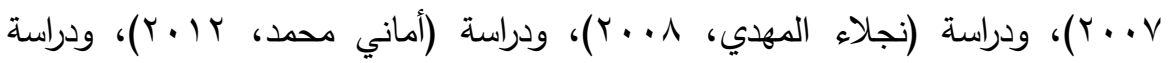

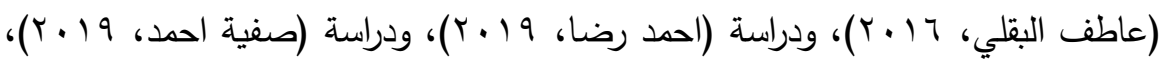
ودراسة (طلعت عبد الرحيم، 9 ( • ب). • • خصائص وسمات العاملين بالجهاز المركزي للتظيم والإدارة.

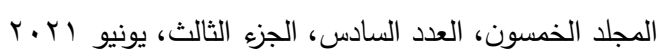


يمر العالم اليوم بمرحلة من التطور والتقدم المعرفي والتكنولوجي ونتج عن ذلك تغير

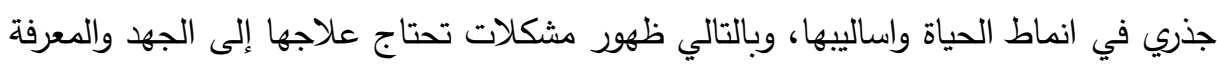
والإهتمام، والعاملين بالمؤسسات الحكومية ليس بمنأي عن تلك التغيرات والتحولات فهم يشهدو

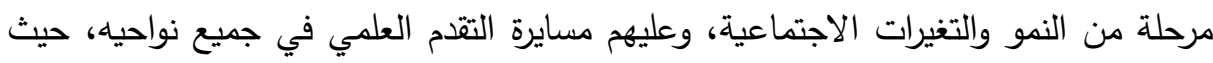

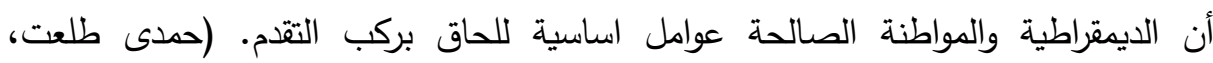
$(1 \cdot Y: 1 \cdot 1$ ) $1 \cdot 1 \leq$

وحيث أن المجتمع يحتاج إلى إحداث تطور في شتي المجالات الاقتصادية والاجتماعية

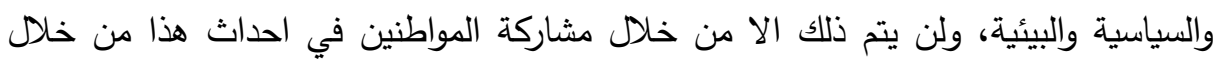

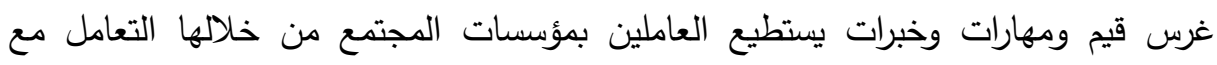
المستقبل ومتغيراته بمسئولية، والحفاظ على البيئة ومواردها. • القضايا والمشكلات البيئية لتنمية المعارف ومهارات حل المشكلات البهات البيئية. تم تحديد مجموعة من القضايا والمشكلات البيئية وهي الأكثر اهمية والحاحا في ذلك العصر وهي كالتالي: - إهدار الموارد البيئية - التلوث البيئي - التغيرات المناخية - المخلفات البيئية

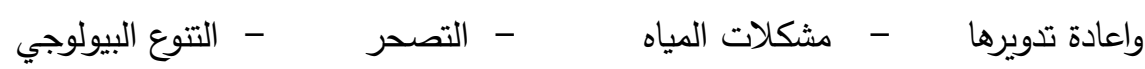
وفي ضوء تلك القضايا والمشكلات الرئيسية تم تحديد المعارف ومهارات حل المشكلات البيئية المرتبطة بها: آراء الخبراء والمتخصصين في التربية البيئية والمناهج وطرق التدريس وعلم النفس فله الصورة الأولية للقائمة: تم عرض القائمة التي تم التوصل اليها على مجموعة من السادة ولئيل

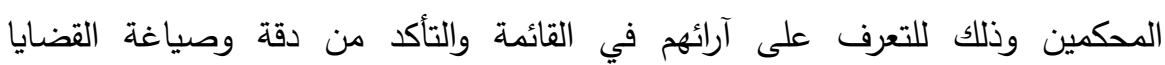
والمشكلات البيئية الواردة في القائمة ووضوحها ومناسبتها للبرنامج التدريبي المقترح ومناسبتها لعينة الدراسة. 
• الصورة النهائية للقائمة: تم تعديل القائمة المبدئية في ضوه آراء السادة المحكمين وأصبحت القائمة النهائية مكونة من (ثمانية) قضايا. وللإجابة عن السؤال الثالث: "ما التصور المقترح للبرنامج التدريبي القائم على استراتيجية المحطات العلمية لتتمية المعارف ومهارات حل المشكلات البيئية لدى العاملين بالجهاز

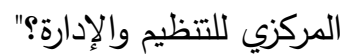
اتبع البحث الإجراءات التالية: إعداد دليل المدرب وبطاقات عمل المتدرب وفقا لاستراتيجية

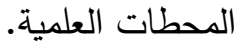
لتصميم البرنامج القائم على استراتيجية المحطات العلمية اتبع البحث الإجراءات التالية: أولاً: أسس بناء البرنامج التدرببي المقترح: الأسس التي اعتمد عليها البحث في بناء البرنامج

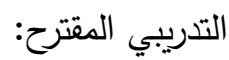

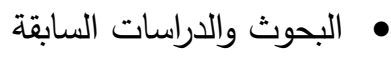
• استراتيجية المحطات العلمية.

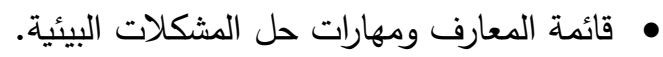
• خصائص وسمات وحاجات العاملين بالجهاز المركزي للتظيم والإدارة. • • خصائص بناء البرامج التدربية

ثانياً: الأهداف العامة للبرنامج التدريبي: الهيف العام للبرنامج: تتمية بعض المعارف ومهارات حل المشكلات البيئية لاى العاملين بالجهاز المركزي للتنظيم والإدارة باستخدام البرنامج التدريبي القائم على استراتيجية المحطات العلمية. الأهداف الخاصة بالبرنامج التدريبي: بعد الإنتهاء من دراسة البرنامج يكون المتدرب قادرًا على: • أن يتعرف على بعض القضايا والمشكلات البيئية المحلية والإقليمية والعالمية.

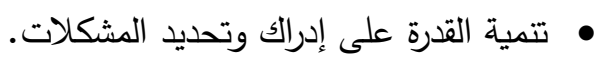
• تمية القدرة على جمع المعلومات والبيانات عن المشكلات وتنظيمها وتحليلها. 
• تمية القدرة على تقديم بدائل لحل المشكلات. • تنمية القدرة على اتخاذ القرار البيئي. • أن يتعرف على دور التكنولوجيا في التعلم. • تقدير دور العلم والعلماء وخاصة في مجال البيئة. • تتمية مهارات التفكير الناقد والابداعي والابتكاري. • تمية مهارا ت العمل الجماعي وروح الفريق. • ت تمية مهارات التعلم الذاتي • أن يكتسب مفاهيم ومعارف بيئية جديدة. • تنمية مهارات حب الاستطلاع والبحث عن المعلومة. • تنمية السلوكيات الصديقة للبيئة. • تمية مهارات عمليات التعلم الاساسية من ملاحظة واستتتاج وتتبؤ وتصنيف وقياس. • • ت تمية الدافعية للتعلم. • أن يكتسب أنواع عديدة من الذكاءات بصري ولغوي وحركي واجتماعي. • تمية الاحساس بمتعة التعلم من خلال ممارسة الأنثطة العملية والمهنية بين الزملاء. • يسهح بنشاط في أداء المهام البيئية. ثالثاً: محتوي البرنامج: إجراءات اختيار محتوى البرنامج التدربي: تم تحديد محتوي البرنامج التدربيي في ضوء الأهداف المحددة سلفا وكذلك في ضوء: • الاطلاع على الادبيات النظرية المتعلقة بموضوع الدراسة. •الاطلاع على قائمة القضايا والمشكلات البيئية. • مراعاة أن تكون مناسبة للخصائص العلقية للفئة المستهدفة • مراعاة تتظيم محتوي البرنامج بثكل منطقي ومناسب للفئة المستهدفة مراعاة قابلية البرنامج للتطبيق العملي. 


$$
\begin{aligned}
& \text { مجلة العلوم البيئية } \\
& \text { معهد الدراسات والبحوث البيئية - جامعة عين شمس البية } \\
& \text { غادة محمد شاد وآخرون }
\end{aligned}
$$

محتوي البرنامج التدريبي: تكون البرنامج التدريبي من عشر جلسات تدريبية، وقد تم تتظيم

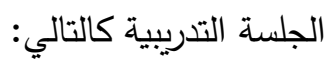
• • عنوان الجلسة: تم اختياره ليكون معبرا عن موضوع الجلسة. • موضوع الجلسة: المفاهيم القضايا المراد تتاولها. • مضمون الجلسة: ملخص لما تحتويه الجلسة التدريبية من أهداف ومحتوي وإجراءات. • مكان تتفيذ الجلسة: داخل قاعة تدريبية مجهزة بمركز إعداد القادة للقطاع الحكومي.

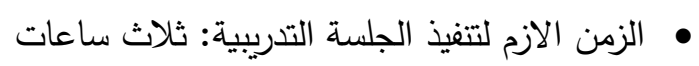
• أهداف الجلسة: تم صياغاتها بصورة إجرائية حتى يمكن التأكد منها وقياسها.

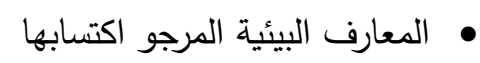
• مهارات حل المشكلات البيئية المرجو اكتسابها. • محتوي الجلسة: وهو العناصر الرئيسية لموضوع الجلسة.

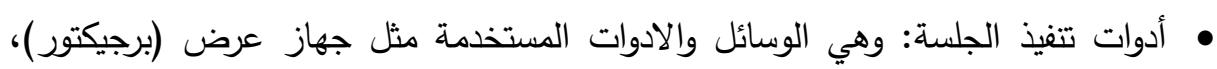
صور، جهاز كمبيوتر ، أوراق، اقلام. • إجراءات تتفيذ الجلسة: تسير كل جلسة وفق استراتيجية المحطات العلمية. رابعا الوسائل والادوات التدريبية المستخدمة في البرنامج: مواد تدريبية مطبوعة، أجهزة كمبيوتر ، شاشة عرض (برجيكتور)، أفلام تعليمية، مقاطع فيديو للمشكلات البيئية، أفلام

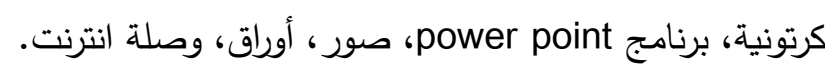
خامساً: أساليب تنفيذ البرنامج: استخدم في تتفيذ البرنامج التدريبي استراتيجية المحطات العلمية التي تتضمن عدد من المحطات العلمية كل محطة تتضمن نشاطا مختلفا يقوم كل مجموعة بالتناوب. سادساً: أساليب التقويم في البرنامج: اولا: التقويم القبلي: وتم ذلك من خلال التطبيق التبلي

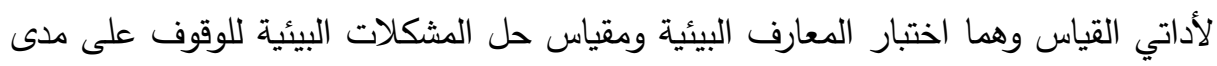

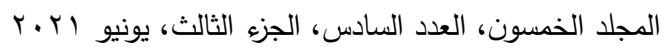

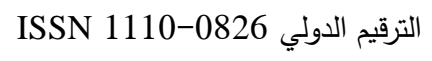


تمكن المتدربين من المعارف ومهارات حل المشكلات البيئية التي يسعى البرنامج التدريبي لتتميتهما. ثانياً: التقويم البنائي: وتم هذا التقويم أثناء تتفيذ البرنامج، وتمثل أوراق العمل المصاحبة لكل محطة وتتضمن مجموعة من الأسئلة يجيب عليها المجموعات بعد أداء كل نثاط داخل كل محطة تعلم ويهدف هذا النوع من التقويم إلى الكثف عن مدى تحقق الأهداف بعد كل جلسة تدريبية، ودمج المتدربين في النشاط التدريبي وضمان المشاركة الفعالة.

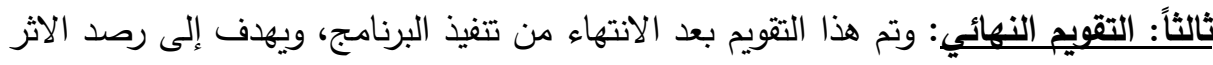
الذي تركه تطبيق البرنامج في تتمية المعارف ومهارات حل المشكلات البيئية لدى المتدربين من أجل الوقوف على مدي تحقق الأهداف الخاصة بالبرنامج التدريبي القائم على استراتيجية المحطات العلمية من خلال التطبيق البعدي لأداتي القياس وهما اختبار المعارف البيئية ومقياس حل المشكلات البيئية. سابعاً: ضبط البرنامج: للتأكد من صلاحية البرنامج التدريبي للتطبيق عرضت الباحثن الباتون البرنامج في صورته الأولية على مجموعة من المحكمين في مجال المناهج وطرق التدريس

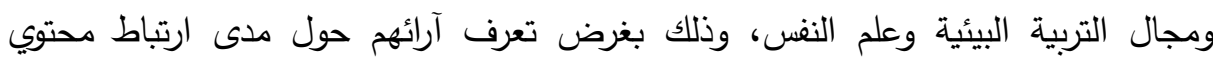

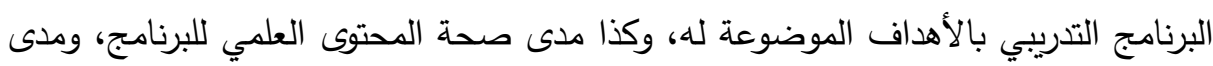
ملاءمته، وملاءمة انثطته للمتدربين عينة البحث، وقد اتقق السداة المحكمون على صحة

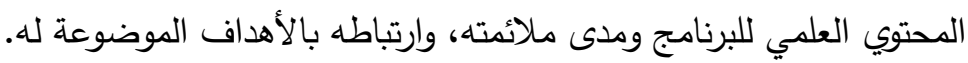

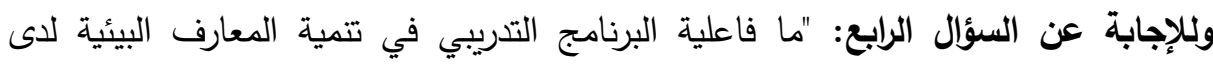

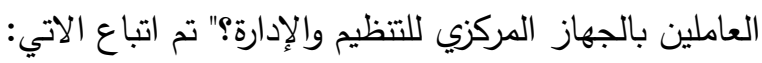

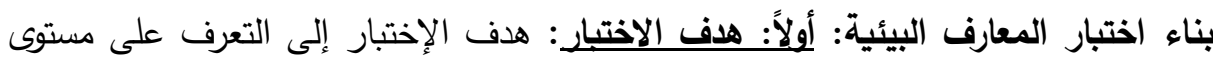
المعارف البيئية لدى العاملين بالجهاز المركزي للتنظيم والإدارة.

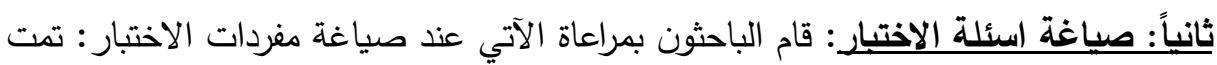

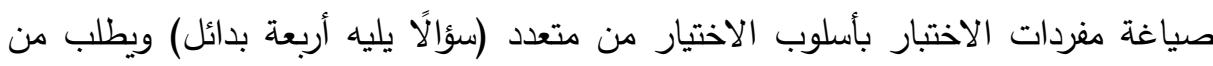
268 
عينة البحث اختيار استجابة واحدة تمثل العبارة الصحيحة، ثم مراعاة الشروط الواجب توافرها

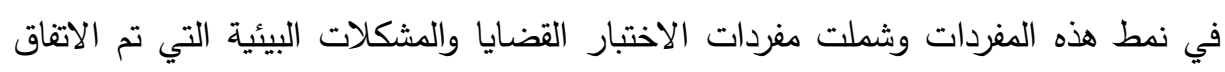
عليها للعاملين بالجهاز المركزي للتتظيم والإدارة عينة البحث.

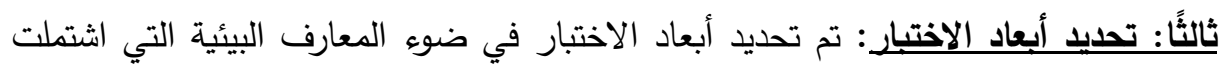
عليها قائمة القضايا والمشكلات البيئية.

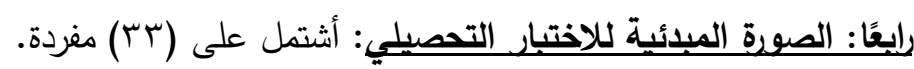
خامسًا: صدق الاختبار التحصيلي: للتأكد من صدق وسلامة الاختبار التحصيلي علميا تم اتباع الآتي: تم عرض الاختبار في صورته الأولية على مجموعة من السادة المحكمين

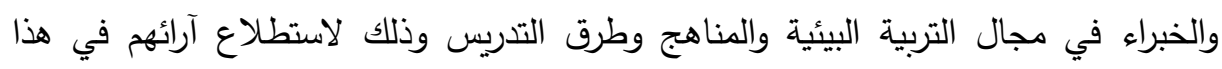

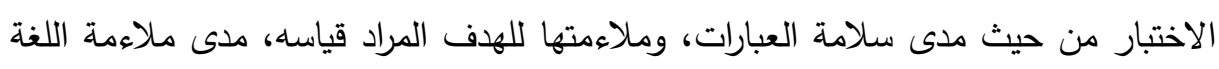

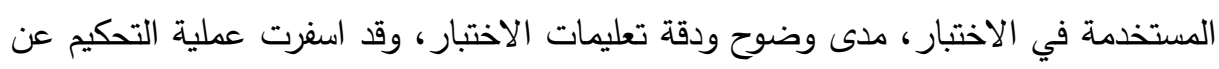

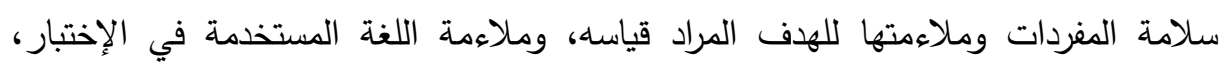
وملاءمة المفردات لعينة البحث وتعديل بعض مفردات الاختبار ، وأصبحت الصورة النهائية

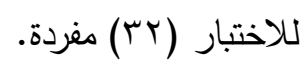
سادسًا: ثبات الاختبار: استخدم الباحثون طريقة معادلة ألفا كرونباخ (Alpha Cronbach) لثبات اختبار المعارف البيئية وبلغت قيمة معامل ألفا للارجة الكلية لاختبار المعارف البيائية

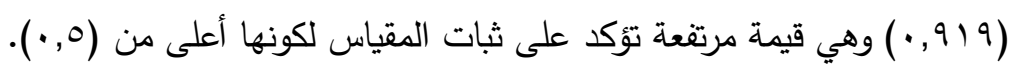

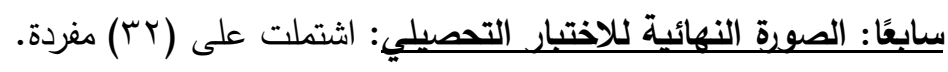

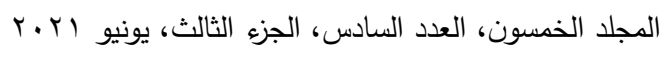

$$
\begin{aligned}
& \text { الترقيم الدولي 0826-0 الندون }
\end{aligned}
$$


جدول (1): مواصفات اختبار المعارف البيئية

\begin{tabular}{|c|c|c|c|c|}
\hline الارجة & عدد المفردات & أرقام المفردات & القضية البيئية & 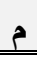 \\
\hline$\varepsilon$ & $\varepsilon$ & (1) & إهدار الموارد البيئية & 1 \\
\hline 0 & 0 & rq, & تلوث البيئة & r \\
\hline$\varepsilon$ & $\varepsilon$ & ع $18617 ، 1)$ & التغيرات المناخية & r \\
\hline$\varepsilon$ & $\varepsilon$ & rN 6rO 6rt6V & المخلفات البيئية واعادة تدويرها & $\varepsilon$ \\
\hline 0 & 0 & r. 6rV 6rT 6r. 69 & مشكلات الغذاء & 0 \\
\hline r & $r$ & YE، TY 610 & مشكلات المياه & 7 \\
\hline r & r & 19614611 & التصحر & V \\
\hline$\varepsilon$ & $\varepsilon$ & 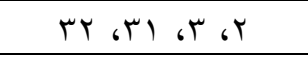 & التتوع البيولوجي & $\Lambda$ \\
\hline t & 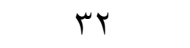 & r & المجموع & \\
\hline
\end{tabular}

ثامنًا: تعليمات الاختبار: راع الباحثون وضع تعليمات الاختبار في الصفحة الأولى مع ذكر

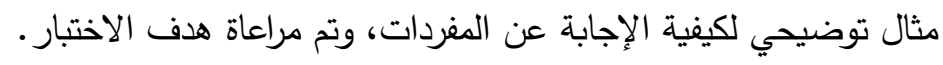

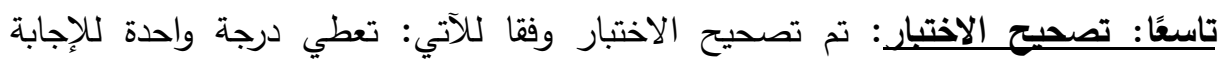
الصحيحة و(صفر) للإجابة غير الصحيحة. وللإجابة عن السؤال الخامس: "ما فاعلية البرنامج التدريبي فى تتمية مهارات حل المشكلات البيئية لدى العاملين بالجهاز المركزي للتنظيم والإدارة؟" تم اتباع الآتي:

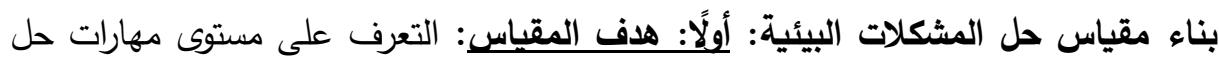
المشكلات البيئة (تحديد المشكلة البيئية، تتظيم المعلومات والبيانات المتعلقة بالمشكلات

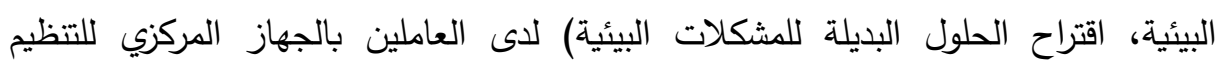

ثانيًا: صياغة عبارات المقياس: تم صياغة المقياس في ضوه قائمة القضايا والمشكلات البيئية، وألا يحتمل الموقف الواحد أكثر من إجابة صحيحة واحدة فقط وذلك في كلًا من: المحور الأول (تحديد المشكلات البيئية)، والمحور الثاني (تنظيم المعلومات والبيانات المتعلقة 
بالمشكلات البيئية)، بينما تم ترك الحرية للمتدرب بوضع أكثر من حل صحيح بالنسبة للمحور الثالث (إقتراح الحلول البديلة للمشكلات البيئية). ثالثًا: تحديد أبعاد المقياس: تم تحديد أبعاد المقياس في ضوه قائمة القضايا والمشكلات البيئية. لإيعًا: الصورة المبئية للمقياس: اشتملت على (عان) مفردة، (9 (1) مفردة للمحور الأول "تحديد المشكلة البيئية"، و(1/) مفردة للمحور الثاني" تتظيم المعلومات والبيانات المتعلقة

بالمشكلات البيئية" و(V V) مغردة للمحور الثالث "إقتراح الحلول البديلة للمشكلات البيئية". خامسًا: صدق المقياس: للتأكد من صدق وسلامة المقياس علميا تم عرض المقدئس المقاس في صورته الأولية على مجموعة من السادة المحكمين والخبراء في مجال التربية البيئية والمناهج وطرق التدريس وذلك لاستطلاع آرائهم في هذا المقياس من حيث مدى سلادمة ملاديه العبارات

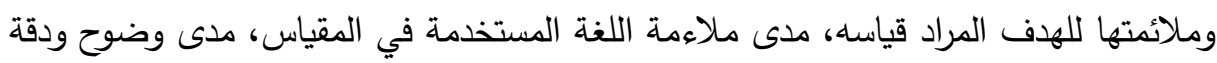

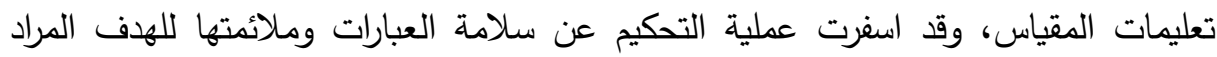
قياسه، وملائمة اللغة المستخدمة في المقياس، كما أشار البعض إلى إعادة صياغة ولعاتهات وتعديل

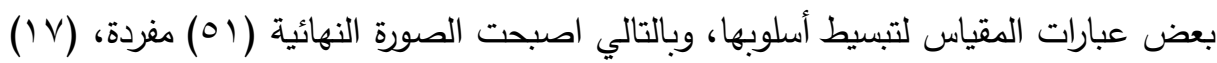

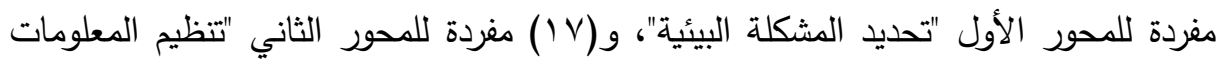

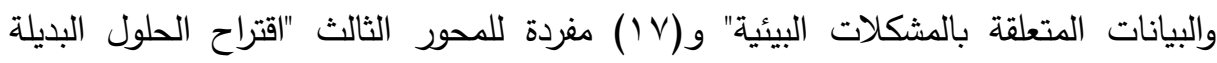

$$
\text { للمشكلات البيئية". }
$$

سادسًا: ثبات المقياس: اعتمد الباحثون على نتائج معادلة ألفا كرونباخ (Alonbach) (Alpha الكلية لمقياس حل المشكلات البيئية (907, • ))، وهي قيمة مرتفعة تؤكد ثبات المقياس لكونها

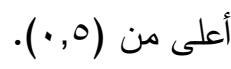


سابعًا: الصورة النهائية للمقياس: اشتملت على (O) مفردة، (IV) مفردة للمحور الأول

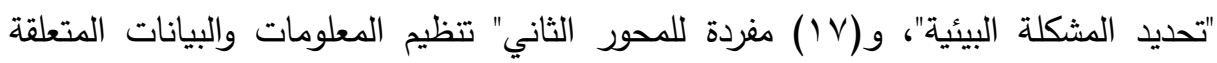
بالمشكلات البيئية" و(V V) مفردة للمحور الثالث "اقتراح الحلول البديلة للمشكلات البيئية". جدول (ץ): مواصفات مقياس حل المشكلات البيئية

\begin{tabular}{|c|c|c|c|}
\hline عدد الارجات & عدد المفردات & محاور مقياس حل المشكلات البيئية & ? \\
\hline iv & IV & المحور الأول "تحديد المشكلات البيئية" & 1 \\
\hline iv & iv & المحور الثاني "تتظيم المعلومات والبيانات" & r \\
\hline$r \varepsilon$ & iv & الدحور الثالث "|قتراح حلول بديلة للدشكلات البيئية" & r \\
\hline 71 & 01 & 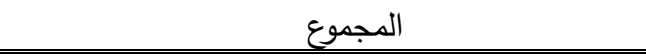 & \\
\hline
\end{tabular}

ثامنًا: تعليمات المقياس: راع الباحثون تحديد هدف المقياس، شرح مختصر لكل محور

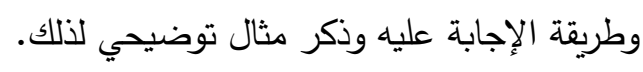

تاسعًا: تصحيح المقياس: تم تصحيح المقياس وفقا للآتي: تعطي درجة واحدة للإجابة

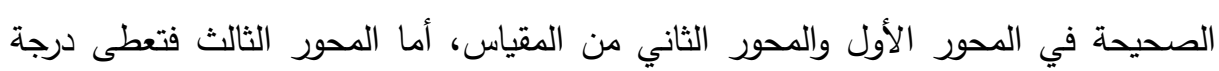

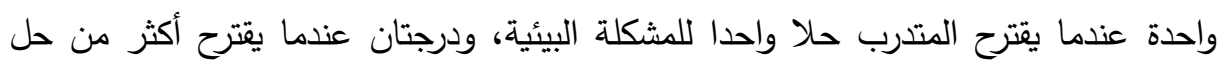
صحيح للمشكلة، ويعطى صفرا عندما لا يكتب حل أو يقدم حلول خاطئة للمشكلة البيئية. عينة البحث: تكونت عينة البحث من مجموعة تجريبية واحدة، وقد تم اختيار مجموعة البحث وعددهم (rr) من العاملين بمركز إعداد القادة للقطاع الحكومي بالجهاز المركزي

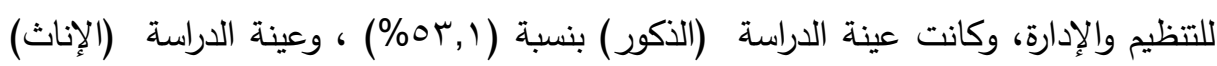

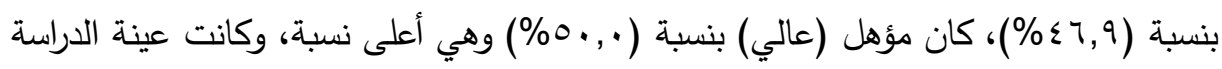

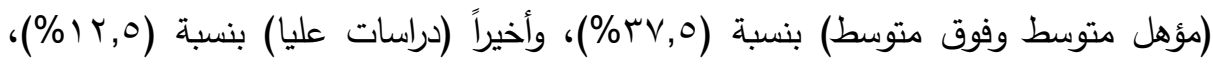

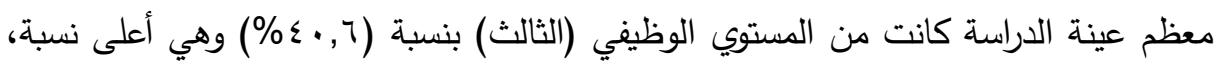

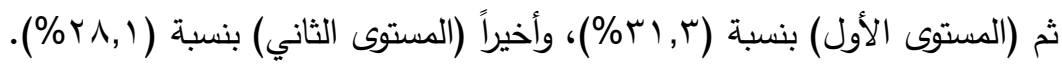


إحلء التطيق القبلي لأداتي البحث: قام الباحثون بتطبيق اداتي البحث (اختبار المعارف البيئية ومقياس حل المشكلات البيئية قبليا على مجموعة البحث (المجموعة التجريبية) بمركز

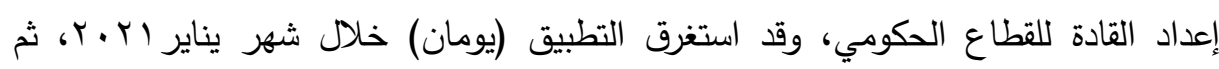
تطبيق البرنامج التدريبي على مجموعة البحث: قام الباحثون بتطبيق البرنامج التدريبي القائم

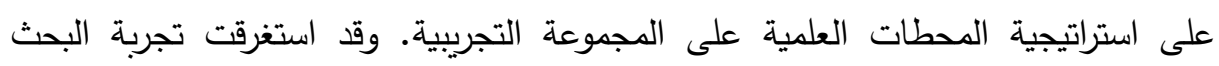

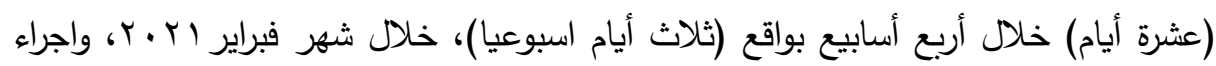

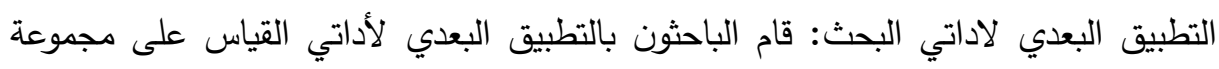

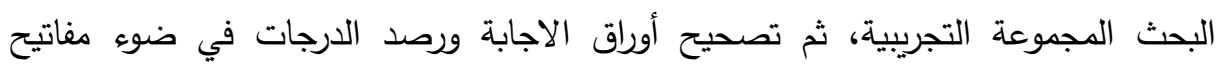
التصحيح الخاصة بكل أداء.

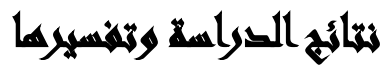

معالجة النتائج في ضوء فروض البحث باستخدام الأساليب الإحصائية تمت معالجة نتائج الدراسة للتحقق من صحة الفروض كما يلي: الفرض الأول: يوجد فرق دال إحصائيًا بين متوسطي درجات المتدربين في التطبيق القبلي وإلتبيق البعدي لصالح التطبيق البعدي لاختبار المعارف البيئية.

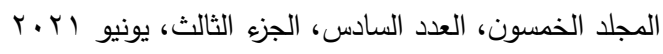

$$
\begin{aligned}
& \text { الترقيم الدولي 0826-0 الندون }
\end{aligned}
$$


مجلة العلوم البيئية

معهد الدراسات والبحوث البيئية - جامعة عين شمس لبه

غادة محمد رشاد وآخرون

جدول (ץ): نتائج اختبار (ت) لحساب دلالة الفروق بين متوسطي درجات عينة الدراسة في التطبيقين القبلي والبعدي اختبار المعارف البيئية

\begin{tabular}{|c|c|c|c|c|c|c|c|}
\hline \multirow{2}{*}{ الدلاية } & \multirow{2}{*}{ قيمة (ت) } & \multicolumn{2}{|c|}{ 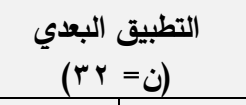 } & \multicolumn{2}{|c|}{ 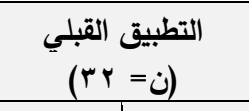 } & \multirow{2}{*}{ الكلية } & \multirow{2}{*}{ المتغيرات } \\
\hline & & الانحراف & المتوسط & الانحراف & المتوسط & & \\
\hline دالة & 1, &., 90 & r, & $\cdot, 9 \wedge$ & 1, & $\varepsilon$ & إهدار الموارد البيئية \\
\hline دالة & $1 \varepsilon, \vee า 7$ & •, & $r, q 1$ & $\cdot, \wedge \vee$ & $1, \Gamma \leq$ & 0 & تلوث البيئة \\
\hline دالة & $V, \Sigma)$ & $1,1 \mathrm{~V}$ & $r, 91$ & $\cdot, \mathrm{\vee} \wedge$ & $1, \cdot r$ & $\varepsilon$ & التغيرات المناخية \\
\hline دالة ل & $\Lambda, \cdot Y)$ & $1, \cdot r$ & $r, r$ & $\cdot, \lambda r$ & $1, .9$ & $\varepsilon$ & المخلفات البيئية وإعادة \\
\hline دالة ل & $1, \cdot 9 r$ & 1, ro & $r, V Y$ & $\cdot, \wedge \vee$ & $1, \Gamma$ & 0 & مشكلات الغذاء \\
\hline دالة ل & ר, & $\cdot, \wedge 7$ & $r, 19$ & $\cdot, \wedge$. & $\cdot, \vee_{0}$ & r & مشكلات المياه \\
\hline دالة ل & $\Lambda, \vee Y \wedge$ & $\cdot, V Y$ & $r, \Sigma V$ & $\cdot, \wedge$. & $\cdot, \vee_{0}$ & r & التصحر \\
\hline دالة & $1 Y, \cdot v q$ & $\cdot, \mathrm{\vee} \wedge$ & $r, .9$ & $\cdot, \vee \vee 9$ & $\cdot, \wedge \wedge$ & $\varepsilon$ & التتوع البيولوجي \\
\hline 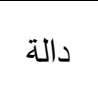 & r., & $r, q 1$ & $r \varepsilon, \varepsilon V$ & $r, 70$ & $\Lambda, r \leqslant$ & rr & الارجة الكلية لاختبار \\
\hline
\end{tabular}

اتضح من جدول (r) لحساب دلالة الفروق بين متوسطي درجات عينة الدراسة في التطبيقين القبلي والبعدي لاختبار المعارف البيئية ما يلي:

• يوجد فرق دال إحصائيًا بين متوسطي درجات المتدربين في التطبيق القبلي والتطبيق

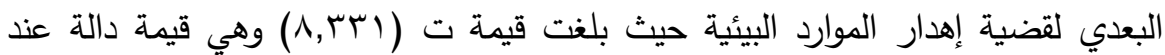
مستوى معنوية (1 .,.)، وكان متوسط درجات عينة التطبيق القبلي (با, (1)، ومتوسط

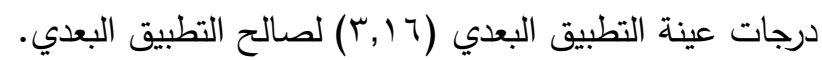
هوجد فرق دال إحصائيًا بين متوسطي درجات المتدربين في التطبيق القبلي والتطبيق

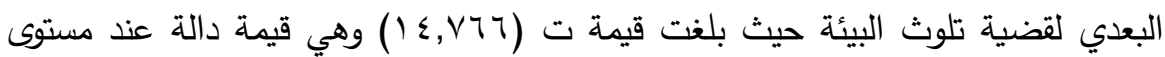

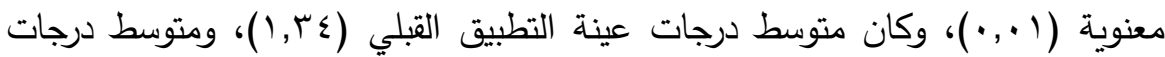

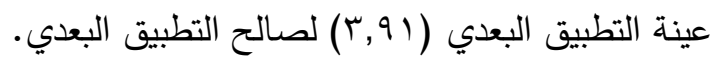


• يوجد فرق دال إحصائيًا بين متوسطي درجات المتدربين في التطبيق القبلي والتطبيق

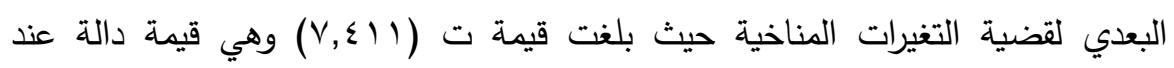

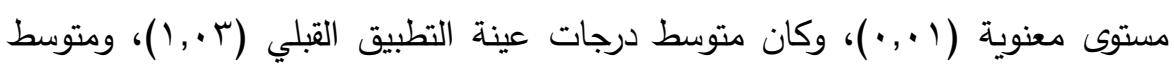

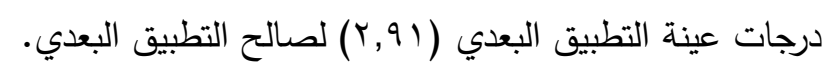

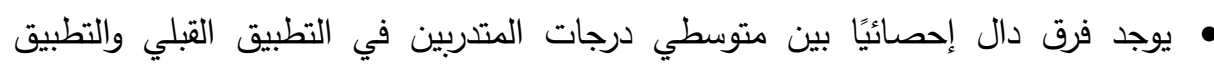

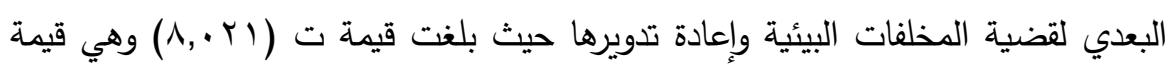
دالة عند مستوى معنوية (1 (,.))، وكان متوسط درجات عينة التطبيق القبلي (9. (, (1)،

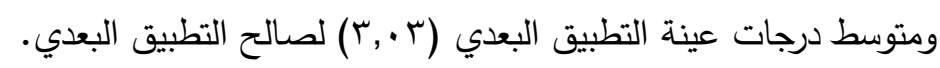
• يوجد فرق دال إحصائيًا بين متوسطي درجات المتدربين في التطبيق القبلي والتطبيق البعايق

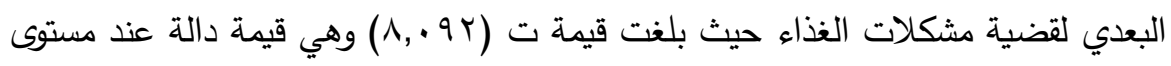

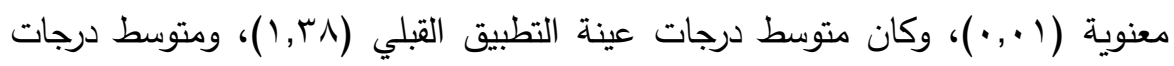

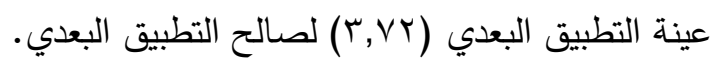

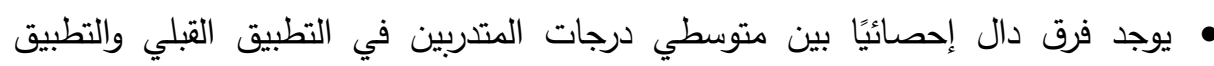

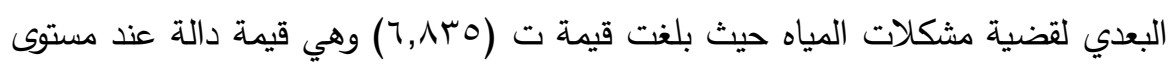

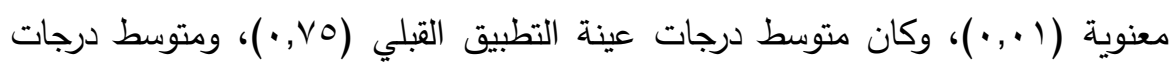

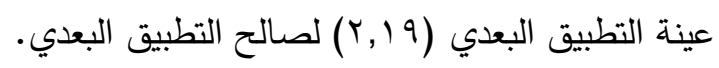
هوجد فرق دال إحصائيًا بين متوسطي درجات المتدربين في التطبيق القبلي والتطبيق

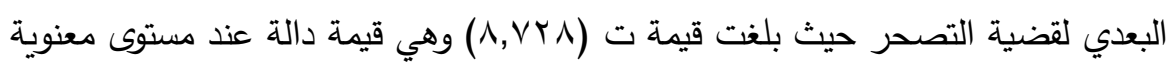

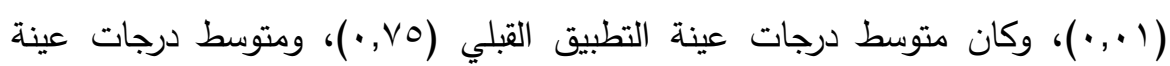

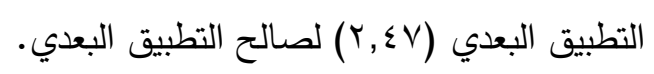

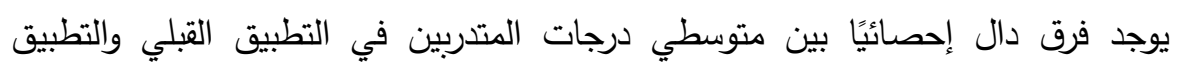

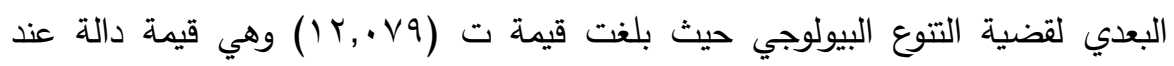

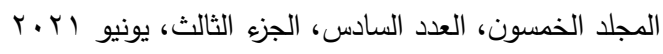

$$
\begin{aligned}
& \text { الترقيم الدولي 0826- 1110 }
\end{aligned}
$$


مستوى معنوية (1 .,.)، وكان متوسط درجات عينة التطبيق القبلي (^^, •)، ومتوسط

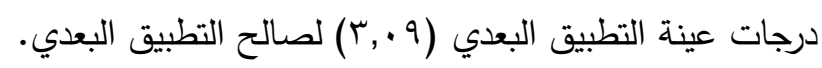
• يوجد فرق دال إحصائيًا بين متوسطي درجات المتدربين في التطبيق القبلي والتطبيق

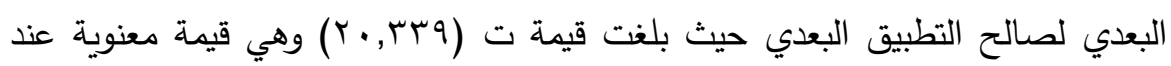

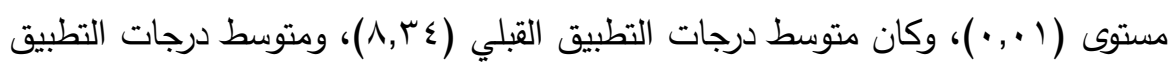

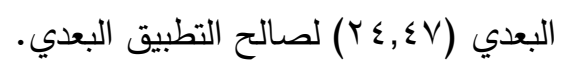

جدول (؛): نتائج حجم التأثير لاختبار المعارف البيئية

\begin{tabular}{|c|c|c|c|}
\hline مقدار حجم التأثير & قيمة d d & قيمة ايتا؟ & المتغيرات \\
\hline متوسط & $\cdot, \mathrm{Vr}$ & .,Or & إهدار الموارد البيئية \\
\hline كبير & $\cdot, 101$ & $\cdot, V Y O$ & تلوث البيئة \\
\hline متوسط & $\cdot, 791$ & $\cdot, \Sigma \vee V$ & التغيرات المناخية \\
\hline متوسط & $\cdot, Y Y Y$ &., 0 , Y & المخلفات البيئية وإعادة تدويرها. \\
\hline متوسط & $\cdot, V \leqslant 1$ &., 00 & مشكلات الغذاء \\
\hline متوسط & $\cdot, 74$. & $\cdot, \leqslant$ \% & مشكلات المياه \\
\hline متوسط & $\cdot, \mathrm{V} 0 \leq$ &., 071 & التصحر \\
\hline كبير & $\cdot, \wedge Y$ &.,$T V K$ & التتوع البيولوجى \\
\hline كبير & $\cdot, 9 \leqslant V$ & $\cdot, \wedge 9 \vee$ & الدرجة الكلية لاختبار المعارف البيئية \\
\hline
\end{tabular}

اتضح من جدول رقم (ع) لنتائج حجم التأثير لاختبار المعارف البيئية أن حجم التأثير

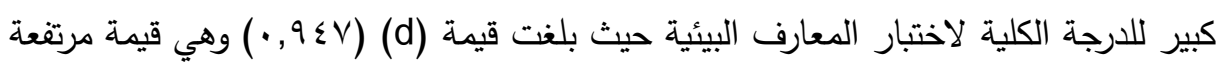

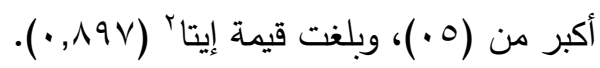

مما سبق تحقق صحة الفرض الأول: يوجد فرق دال إحصائًا بين متوسطي درجات النيات

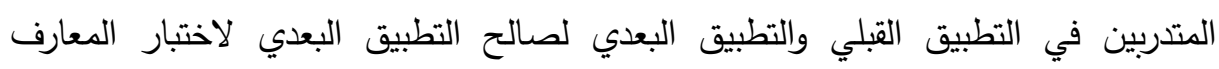


الفرض الثاني: يوجد فرق دال إحصائيًا بين متوسطي درجات المتدربين في التطبيق القبلي والتطبيق البعدي لصالح التطبيق البعدي لمقياس حل المشكلات البيئية. جدول (0): نتائج اختبار (ت) لحساب دلالة الفروق بين متوسطي درجات عينة الدراسة في التطبيقين القبلي والبعدي للمحور الأول: تحديد المشكلات البيئية

\begin{tabular}{|c|c|c|c|c|c|c|c|}
\hline \multirow{2}{*}{ الدلالة } & \multirow{2}{*}{ قيمة } & \multicolumn{2}{|c|}{ 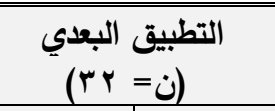 } & \multicolumn{2}{|c|}{ 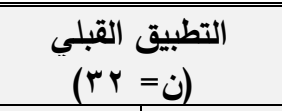 } & \multirow{2}{*}{ الارجة } & \multirow{2}{*}{ المتغيرات } \\
\hline & & الانحراف & المتوسط & الانحراف & المتوسط & & \\
\hline دالة & $V, 0.7$ &., 0 & 1,07 & $\cdot, 7 V$ & $\cdot, 0$ & $r$ & إهدار الموارد البيئية \\
\hline دالة & 9,119 & $\cdot, 10$ & $r, r \wedge$ & $\cdot, 7$. & . & $r$ & تلوث البيئة \\
\hline 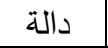 & $\varepsilon, Y \neg V$ & $\cdot, \wedge \varepsilon$ & 1,07 & $\cdot, 9 \leq$ & מדו & r & التغيرات المناخية \\
\hline دالة ل & $7, Y \vee 1$ & •, Tr & 1,0 . & $\cdot, 71$ & $\cdot, 09$ & r & المخلفات البيئية \\
\hline دالة ل & $7,9 \wedge 1$ &., 00 & 1,77 &., $0 \mathrm{~V}$ & $\cdot, \vee_{0}$ & $r$ & مشكلات الغذاء \\
\hline دالة & ( & $\cdot, 7 r$ & 1,07 & $\cdot, 7 r$ & $\cdot, 0$ & r & مشكلات المياه \\
\hline دالة & 0,r. & $\cdot, T V$ & 1,07 & $\cdot, v_{1}$ & ש & $r$ & التصحر \\
\hline دالة & $9, \ldots \varepsilon$ & $\cdot, 71$ & $1, \Gamma \wedge$ &., 07 &., 09 & $r$ & التنوع البيولوجي \\
\hline دالة & $|\wedge, \Sigma Y|$ & $\Delta \vee .1$ & $1 T, \cdot T$ & $1, r v$ & $\varepsilon, \wedge \varepsilon$ & iv & المحور الأول: تحديد البئية \\
\hline
\end{tabular}

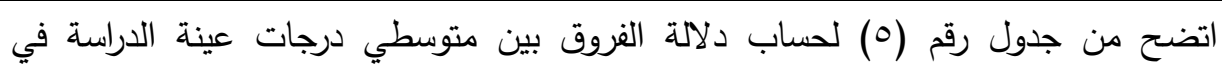

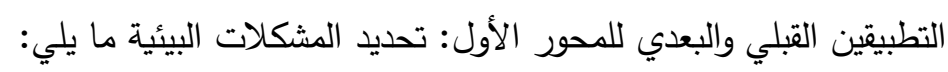
• يوجد فرق دال إحصائيًا بين متوسطي درجات المتدربين في التطبيق القبلي والتطبيق لتئيل

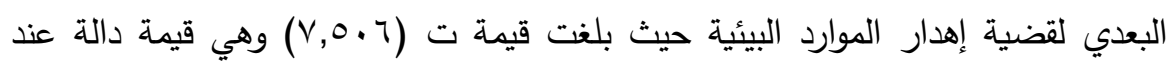

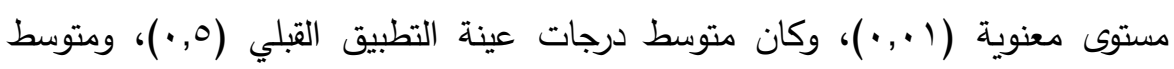

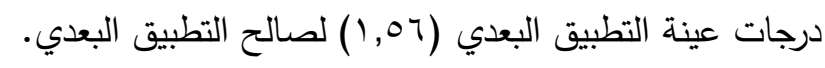
• يوجد فرق دال إحصائيًا بين متوسطي درجات المتدربين في التطبيق القبلي والتطبيق البيقي

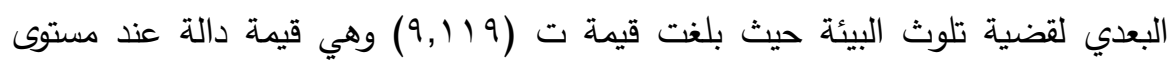


معنوية (1 (., ))، وكان متوسط درجات عينة التطبيق القبلي (77, ·)، ومتوسط درجات

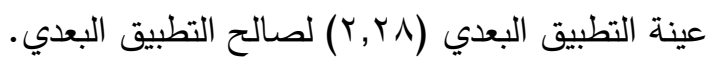
• يوجد فرق دال إحصائيًا بين متوسطي درجات المتدربين في التطبيق القبلي والتطبيق

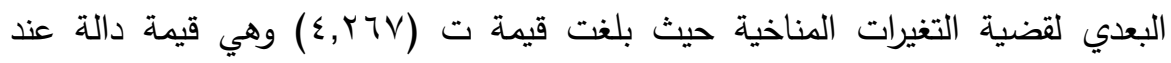

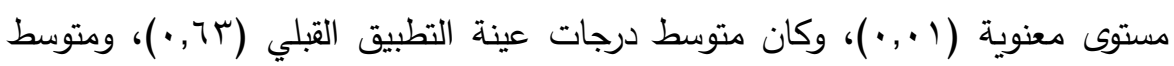
درجات عينة التطبيق البعدي (1,07 1) لصالح التطبيق البعدي.

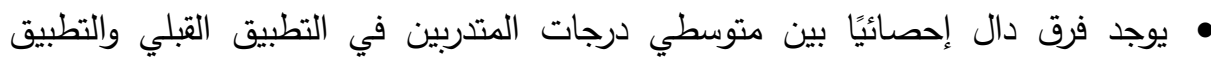

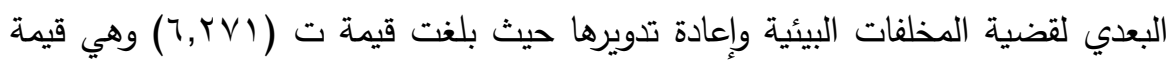
دالة عند مستوى معنوية (1 (, •)، وكان متوسط درجات عينة التطبيق القبلي (ه9,.•)؛ ومتوسط درجات عينة التطبيق البعدي (1, (1) لصالح التطبيق البعدي. • يوجد فرق دال إحصائيًا بين متوسطي درجات المتدربين في التطبيق القبلي والتطبيق

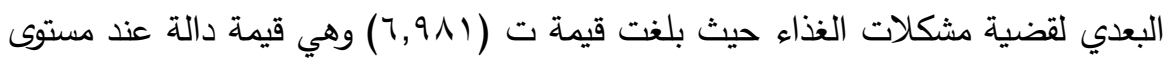
معنوية (1 (., )، وكان متوسط درجات عينة التطبيق القبلي (V0,·)، ومتوسط درجات

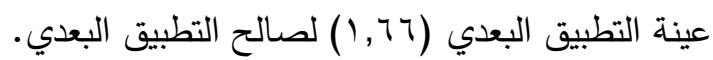
•يوجد فرق دال إحصائيًا بين متوسطي درجات المتدربين في التطبيق القبلي والتطبيق

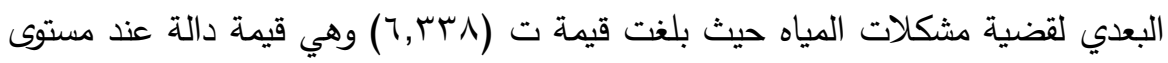
معنوية (1 (., )، وكان متوسط درجات عينة التطبيق القبلي ( (0, •)، ومتوسط درجات

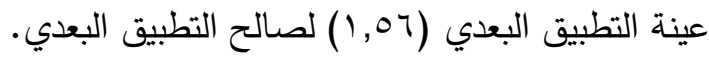
هوجد فرق دال إحصائيًا بين متوسطي درجات المتدربين في التطبيق القبلي والتطبيق

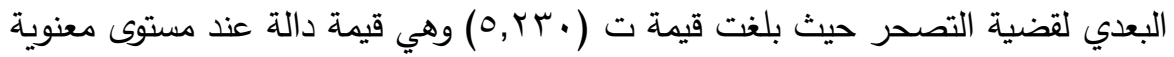

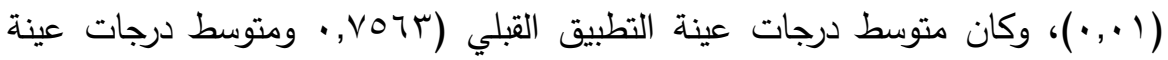

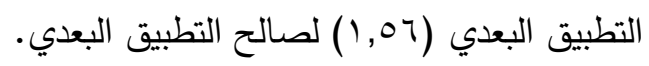


• يوجد فرق دال إحصائيًا بين متوسطي درجات المتدربين في التطبيق القبلي والتطبيق

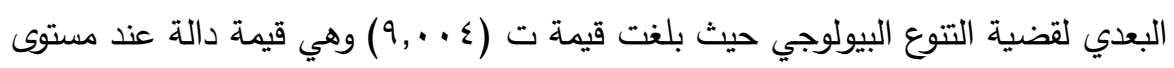
معنوية (1 (., )، وكان متوسط درجات عينة التطبيق القبلي (ه9.•)، ومتوسط درجات

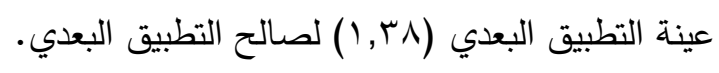

• يوجد فرق دال إحصائيًا بين متوسطي درجات المتدربين في التطبيق القبلي والتطبيق التيقي

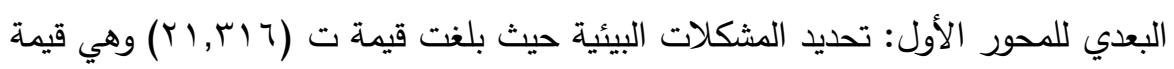

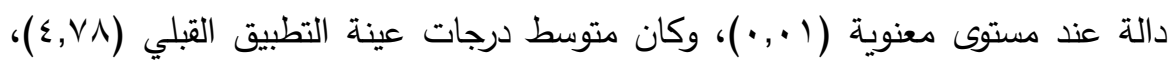

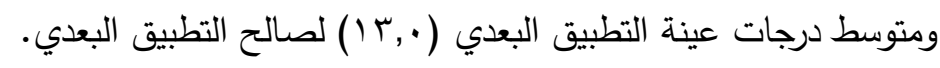
جدول (†): نتائج حجم التأثير للمحور الأول: تحديد المشكلات البيئية

\begin{tabular}{|c|c|c|c|}
\hline مقدار حجم التأثير & قيمة d & 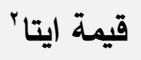 & 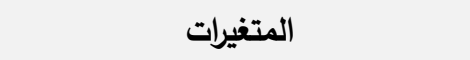 \\
\hline متوسط & $\cdot, \leqslant O Y$ & $\cdot, T V Y$ & إهدار الموارد البيئية \\
\hline متوسط & $\cdot, 007$ & $\cdot, V \leqslant 7$ & تلوث البيئة \\
\hline صغير & $\cdot, Y M T$ & $\cdot, \sum \vee V$ & التغيرات المناخية \\
\hline صغير & $\cdot$, roV &., $09 \mathrm{~V}$ & المخلفات البيئية وإعادة تدويرها \\
\hline صغير & $\cdot, \varepsilon \cdot 7$ & $\cdot, 7 \pi \mathrm{V}$ & مشكلات الغذاء \\
\hline صغير & $\cdot, \varepsilon \pi$ &., 707 & مشكلات المياه \\
\hline صغير & •, rY &., 079 & التصحر \\
\hline صغير & $\cdot, \Gamma 10$ &., 071 & التتوع البيولوجى \\
\hline كبير &., $9 \leq 1$ & $\cdot, \wedge \wedge \mathrm{T}$ & المحور الأول: تحديد المشكلات البيئية \\
\hline
\end{tabular}

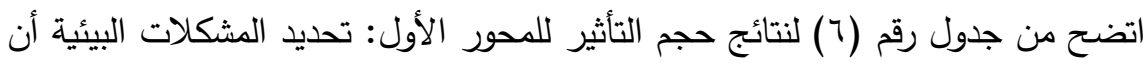

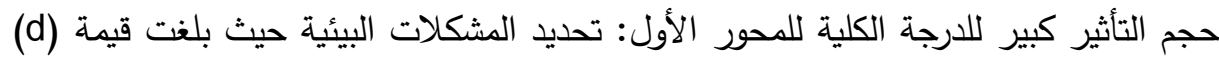

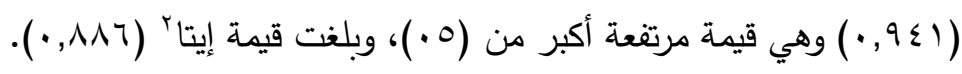


مجلة العلوم البيئية

معهد الدراسات والبحوث البيئية - جامعة عين شمس لئن

غادة محمد رشاد وآخرون

جدول (V): نتائج اختبار (ت) لحساب دلالة الفروق بين متوسطي درجات عينة الدراسة في

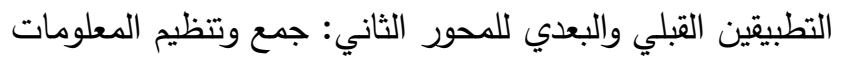

\begin{tabular}{|c|c|c|c|c|c|c|c|}
\hline \multirow{2}{*}{ الدلالة } & \multirow{2}{*}{$\begin{array}{l}\text { قيمة } \\
\text { (ت) }\end{array}$} & \multicolumn{2}{|c|}{ 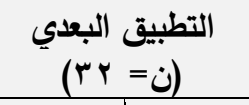 } & \multicolumn{2}{|c|}{ التطبيق القبلي } & \multirow{2}{*}{ الإرجة } & \multirow{2}{*}{ المتغيرات } \\
\hline & & الانحراف & المتوسط & الانحراف & المتوسط & & \\
\hline دالة & $V, \ldots 7$ &., $0 \mathrm{~V}$ & 1,01 &., 07 & $\cdot, 07$ & r & إهدار الموارد البيئية \\
\hline دالة & $\vee, 910$ & $\cdot, 71$ & 1,7 & $\cdot, 07$ & $\cdot, 07$ & r & تلوث البيئة \\
\hline دالة & $\Lambda, \cdots \varepsilon$ & $\cdot, 0 \mathrm{~V}$ & 1,01 & $\cdot, 00$ & • & r & التغيرات المناخية \\
\hline دالة ل & $7, \vee V$ & $\cdot, \leqslant 9$ & 1, 1, & $\cdot, v_{1}$ &., 09 & r & المخلفات البيئية وإعادة \\
\hline دالة & 7,194 & $\cdot, v \varepsilon$ & $Y, M_{I}$ & $\cdot, 9$ & $1, \cdot r$ & r & مشكلات الغذاء \\
\hline دالة & r,vro & $\cdot, T V$ & $1, \leqslant V$ & אד, • & $\cdot, V Y$ & r & مشكلات المياه \\
\hline دالة & $7, \wedge \leq 9$ & $\cdot, 71$ & 1,7 & $\cdot, 7 V$ &., 07 & r & التصحر \\
\hline دالة & 9,010 &., 00 & 1,77 &., 00 & $\cdot, \Gamma \varepsilon$ & $r$ & التتوع البيولوجى \\
\hline دالة & YI, $\{r$ & 1,01 & IT, ז人 & 1,00 & $0, \ldots$ & iv & المحور الثاني: جمع \\
\hline
\end{tabular}

اتضح من جدول (V) لحساب دلالة الفروق بين متوسطي درجات عينة الدراسة في التطبيقين

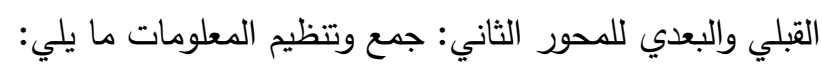

• يوجد فرق دال إحصائيًا بين متوسطي درجات المتدربين في التطبيق القبلي والتطبيق

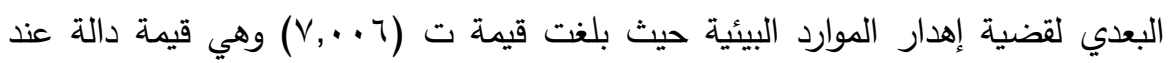

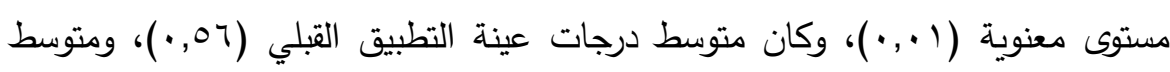

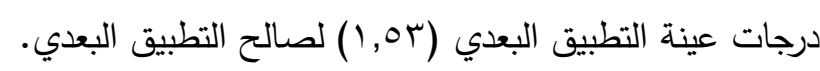

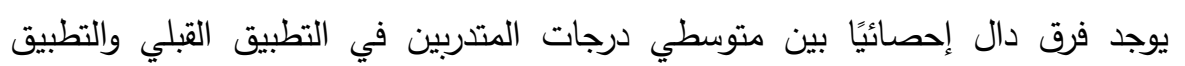

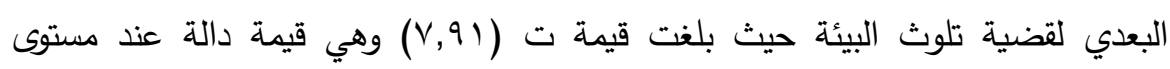
معنوية (1... •)، وكان متوسط درجات عينة التطبيق القبلي (107. •)، ومتوسط درجات

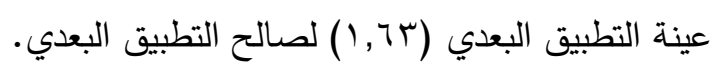


• يوجد فرق دال إحصائيًا بين متوسطي درجات المتدربين في التطبيق القبلي والتطبيق

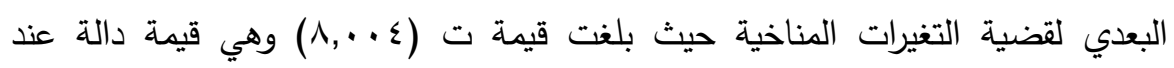

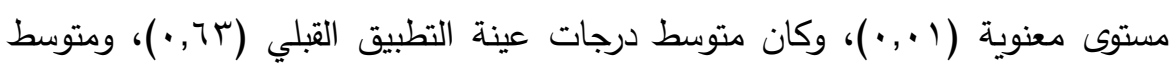

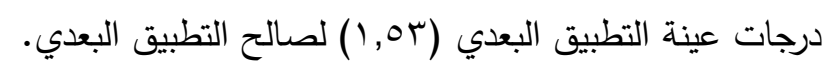
• يوجد فرق دال إحصائيًا بين متوسطي درجات المتدربين في التطبيق القبلي والتطبيق

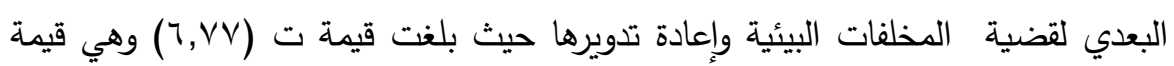

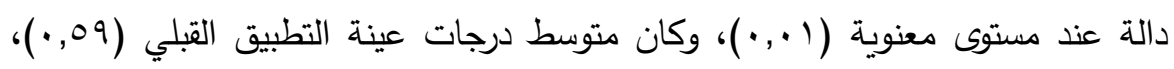

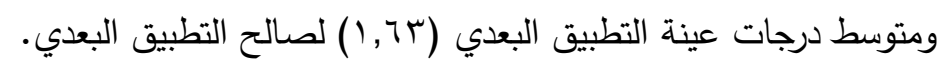

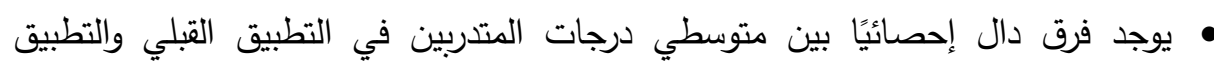

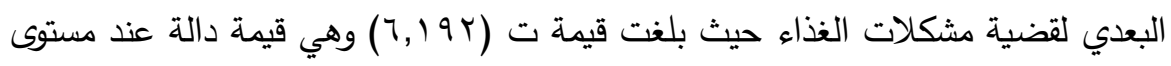
معنوية (1 (.,·)، وكان متوسط درجات عينة التطبيق القبلي (r., (l)، ومتوسط درجات

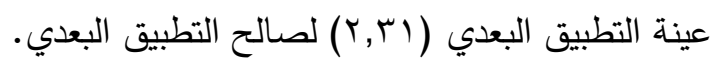
• يوجد فرق دال إحصائًا بين متوسطي درجات المتدربين في التطبيق القبلي والتطبيق التباتيق

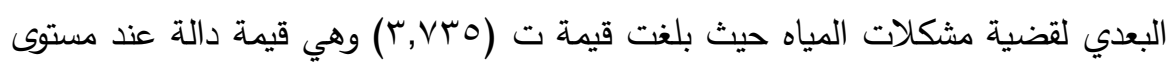
معنوية (1 (., )، وكان متوسط درجات عينة التطبيق القبلي (YY, •))، ومتوسط درجات

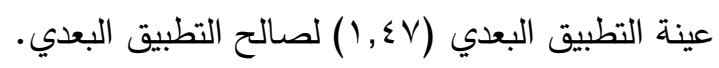
هوجد فرق دال إحصائًا بين متوسطي درجات المتدربين في التطبيق القبلي والتطبيق

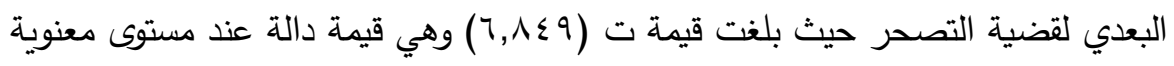
(1., •)، وكان متوسط درجات عينة التطبيق القبلي (107,·) ومتوسط درجات عينة

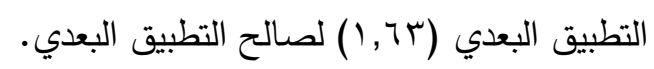
هوجد فرق دال إحصائيًا بين متوسطي درجات المتدربين في التطبيق القبلي والتطبيق البعايق البعدي لقضية التتوع البيولوجي حيث بلغت قيمة ت (9,010) وهي قيمة دالة عند مستوى دئون

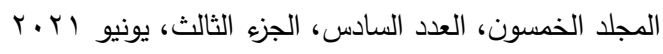

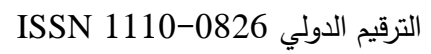


معنوية (1 (, •)، وكان متوسط درجات عينة التطبيق القبلي (ع ب, ·)، ومتوسط درجات

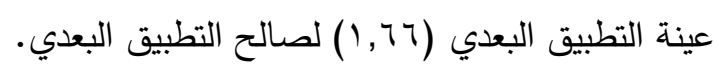
• يوجد فرق دال إحصائيًا بين متوسطي درجات المتدربين في التطبيق القبلي والتطبيق البعان التيقيق

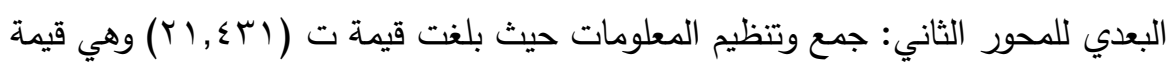
دالة عند مستوى معنوية (1 •,.)، وكان متوسط درجات عينة التطبيق القبلي ( (., ))،

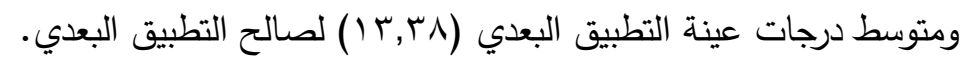

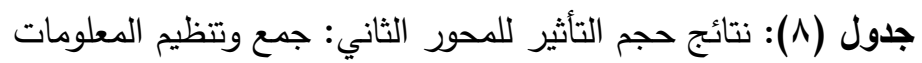

\begin{tabular}{|c|c|c|c|}
\hline مقدار حجم التأثير & قيمة d a & 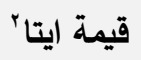 & 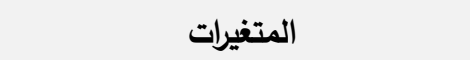 \\
\hline متوسط & $\cdot, \varepsilon \pi$ &., 707 & إهدار الموارد البيئية \\
\hline متوسط & $\cdot, \leqslant 0 \wedge$ & $\cdot$, TVV & تلوث البيئة \\
\hline متوسط & $\cdot, \varepsilon \cdot r$ & . & التغيرات المناخية \\
\hline متوسط & . &., 70 & المخلفات البيئية وإعادة تدويرها \\
\hline متوسط & $\cdot, \Gamma \wedge \uparrow$ &., $7 T_{1}$ & مشكلات الغذاء \\
\hline متوسط & $\cdot$, YO &., $0 . \varepsilon$ & مشكلات المياه \\
\hline متوسط & $\cdot, 817$ & $\cdot, 7 \leqslant 0$ & التصحر \\
\hline متوسط &., 099 & $\cdot, \vee \vee \vee \varepsilon$ & التتوع البيولوجى \\
\hline كبير & $\cdot, 947$ & $\cdot, \wedge \vee 4$ & المحور الثاني: جمع وتتظيم المعلومات \\
\hline
\end{tabular}

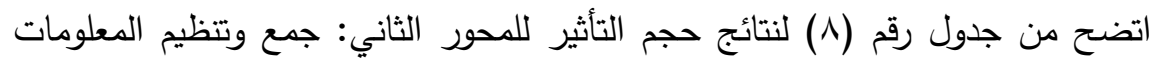

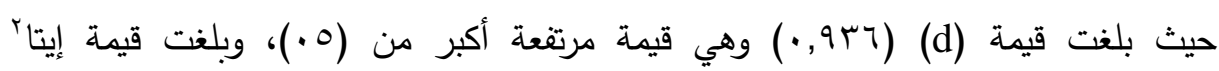
$\cdot(\cdot, \wedge \vee \top)$ 
مجلة العلوم البيئية

معهد الدراسات والبحوث البيئية - جامعة عين شمس لبه

غادة محمد رشاد وآخرون

جدول (9): نتائج اختبار (ت) لحساب دلالة الفروق بين متوسطي درجات عينة الدراسة في التطبيقين القبلي والبعدي لمقياس حل المشكلات البيئية

\begin{tabular}{|c|c|c|c|c|c|c|c|}
\hline \multirow{2}{*}{ الا مستوى } & \multirow{2}{*}{ قيمة } & \multicolumn{2}{|c|}{ 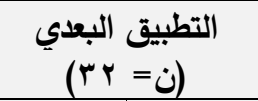 } & \multicolumn{2}{|c|}{ 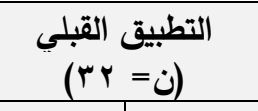 } & \multirow{2}{*}{ الكلية } & \multirow{2}{*}{ المتغيرات } \\
\hline & & الانحراف & المتوسط & الانحراف & المتوسط & & \\
\hline دالة & $1 \cdot, 091$ & $\cdot, 91$ & سו, & $\cdot, v \leqslant$ & $1, r$ & $\varepsilon$ & إهدار الموارد البيئية \\
\hline دالة & $9,91 \mathrm{~V}$ & $1, \cdot \varepsilon$ & $\varepsilon, \Gamma \varepsilon$ & $\cdot, 99$ & $1, V Y$ & 7 & تلوث البيئة \\
\hline دالة & 9,10 . & $1, \cdot 1$ & r,Y & $\cdot, \mathrm{VA}$ & $1, .9$ & r & التغيرات المناخية \\
\hline دالة & I T, T० & $\cdot, \mathrm{VA}$ & $r, .9$ & $\cdot, \wedge 7$ & $1, \cdot 9$ & $\varepsilon$ & المخلفات وإعادة تدويرها. \\
\hline دالة & $\wedge, \Sigma) \wedge$ &., 90 & T, $9 \varepsilon$ & $\cdot, \vee \vee T$ & $\cdot, 9 \leq$ & $\varepsilon$ & مشكلات الغذاء \\
\hline دالة & $1 \cdot, r \leqslant 9$ & חוג, & r,Y & $\cdot, V \leq$ & 1,19 & $\varepsilon$ & مشكلات المياه \\
\hline دالة ل & $9,7 \leqslant \wedge$ & • & r,Y & $\cdot, \wedge \vee$ & 1,1 & $\varepsilon$ & التصحر \\
\hline دالة & $\Lambda, 9 \mu \mathrm{V}$ & $\cdot, \Lambda T$ & $r, \cdot r$ & $\cdot, V \varepsilon$ & 1,19 & $\varepsilon$ & التتوع البيولوجى \\
\hline دالة ل & 19,00 & $r, \varepsilon V$ & Yo, ^ $\varepsilon$ & $r, q$. & $q, \mathrm{r}_{\wedge}$ & TE & المحور الثالث: اقتراح \\
\hline دالة & דr & $\varepsilon, .0$ & or, 19 & & $19,1 \pi$ & $7 \wedge$ & حل الدرجة الكلية لمقياس البئية \\
\hline
\end{tabular}

اتضح من جدول رقم (9) لحساب دلالة الفروق بين متوسطي درجات عينة الدراسة في التطبيقين القبلي والبعدي للمحور الثاني: جمع وتنظيم الدعلومات ما يلي: • يوجد فرق دال إحصائيًا بين متوسطي درجات المتدربين في التطبيق القبلي والتطبيق البعدي لقضية إهدار الموارد البيئية حيث بلغت قيمة ت (14.091 • () وهي قيمة دالة عند مستوى معنوية (1 (., )، وكان متوسط درجات عينة التطبيق القبلي (ب., (1)، ومتوسط

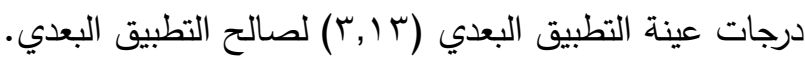
• يوجد فرق دال إحصائيًا بين متوسطي درجات المتدربين في التطبيق القبلي والتطبيق

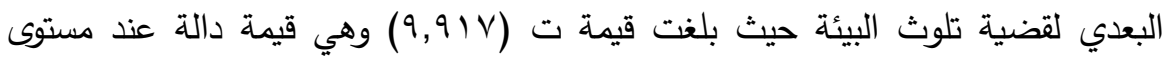


معنوية (1 (., •)، وكان متوسط درجات عينة التطبيق القبلي (I,YY)، ومتوسط درجات

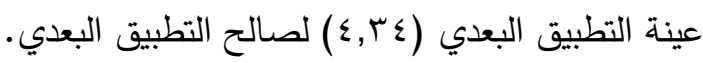
• يوجد فرق دال إحصائيًا بين متوسطي درجات المتدربين في التطبيق التبلي والتطبيق لبطيق

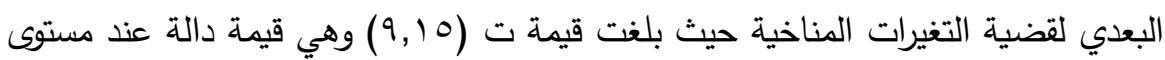
معنوية (1 (., ))، وكان متوسط درجات عينة التطبيق القبلي (9., (1)، ومتوسط درجات

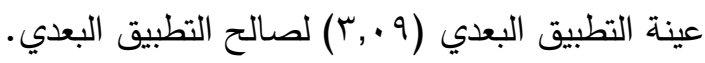
• يوجد فرق دال إحصائيًا بين متوسطي درجات المتدربين في التطبيق التبلي والتطبيق

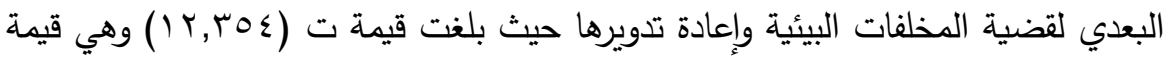
دالة عند مستوى معنوية (1.,.)، وكان متوسط درجات عينة التطبيق القبلي (9.,., (1)، ومتوسط درجات عينة التطبيق البعدي (9 . ,r) لصالح التطبيق البعدي. • يوجد فرق دال إحصائيًا بين متوسطي درجات المتدبين في التطبيق القبلي والتطبيق

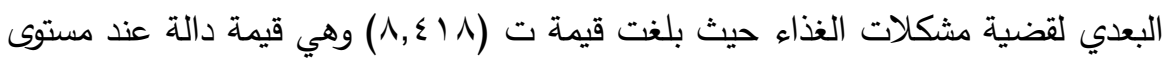
معنوية (1 (.,))، وكان متوسط درجات عينة التطبيق القبلي (ع 9. •)، ومتوسط درجات

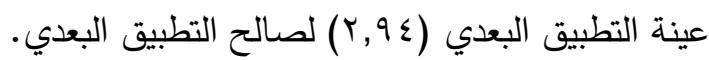
هوجد فرق دال إحصائيًا بين متوسطي درجات المتدربين في التطبيق القبلي والتطبيق البطيق

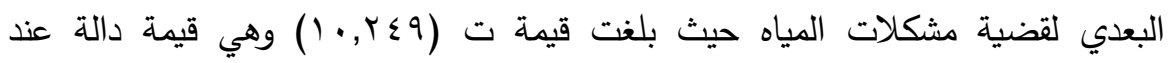

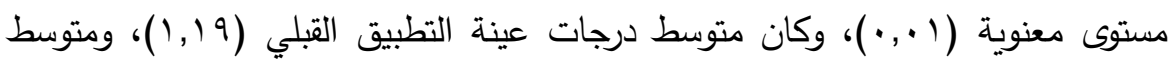

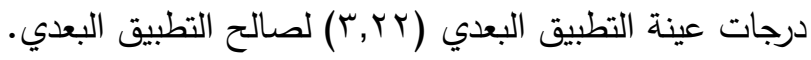
هوجد فرق دال إحصائيًا بين متوسطي درجات المتدربين في التطبيق القبلي والتطبيق

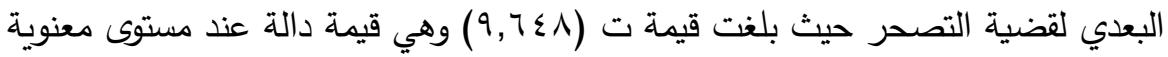
(1,.,)، وكان متوسط درجات عينة التطبيق القبلي (r, (1) ومتوسط درجات عينة التطبيق البعدي (r,r,r) لصالح التطبيق البعدي. 
• يوجد فرق دال إحصائيًا بين متوسطي درجات المتدربين في التطبيق التبلي والتطبيق

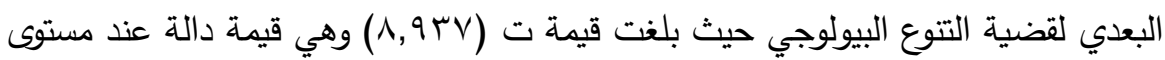
معنوية (1.,.)، وكان متوسط درجات عينة التطبيق القبلي (9, (1,)، ومتوسط درجات

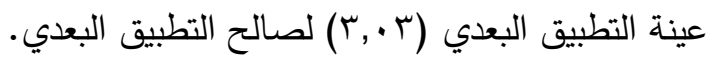
• يوجد فرق دال إحصائيًا بين متوسطي درجات المتدربين في التطبيق القبلي والتطبيق

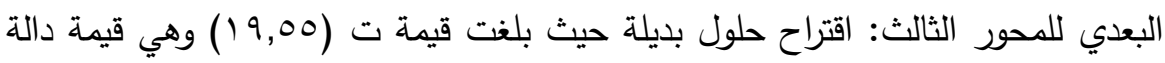

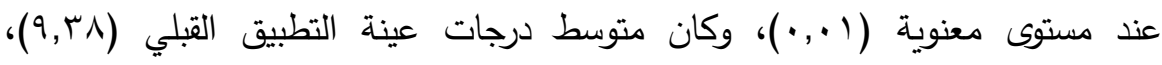

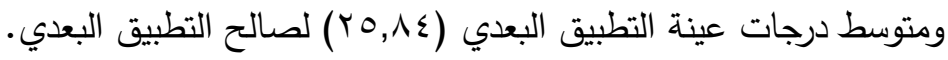
• يوجد فرق دال إحصائيًا بين متوسطي درجات المتدربين في التطبيق التبلي والتطبيق

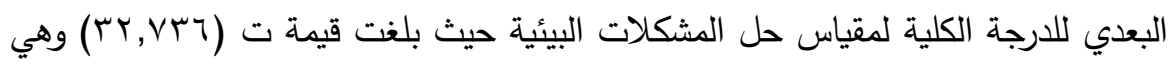
قيمة دالة عند مستوى معنوية (1.,.•)، وكان متوسط درجات عينة التطبيق القبلي

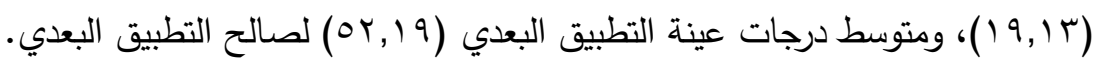
جدول ( • (): نتائج حجم التأثير للمحور الثالث: اقتراح حلول بديلة

\begin{tabular}{|c|c|c|c|}
\hline مقدار حجم التأثير & قيمة d d & قيمة ايتا؟ & المتغيرات \\
\hline متوسط & . & $\cdot, \vee \wedge \wedge$ & إهدار الموارد البيئية \\
\hline متوسط & . & $\cdot, \vee \vee 97$ & تلوث البيئة \\
\hline متوسط &., 09 & $\cdot, \vee \vee \neg \Lambda$ & التغيرات المناخية \\
\hline متوسط & $\cdot, \mathrm{T} \cdot \mathrm{V}$ & $\cdot, \vee \vee \vee q$ & المخلفات وإعادة تدوبرها. \\
\hline متوسط & $\cdot, 0 \wedge \mathrm{r}$ & $\cdot, \vee \vee \neg \varepsilon$ & مشكلات الغذاء \\
\hline متوسط & 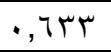 & $\cdot, \mathrm{V} 90$ & مشكلات المياه \\
\hline صغير & $\cdot, \leqslant 9$. & $\cdot, \mathrm{V} \ldots$ & التصحر \\
\hline متوسط &., $\mathrm{OVV}$ & $\cdot, \vee \vee 7$ & التتوع البيولوجي \\
\hline 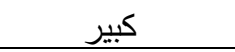 & $\cdot, 94 \leqslant$ & $\cdot, \Lambda \vee T$ & المحور الثالث: اقتراح حلول بديلة \\
\hline كبير & $\cdot, 9 \vee 7$ & $\cdot, 904$ & الدرجة الكلية لمقياس حل المشكلات البيئية \\
\hline
\end{tabular}

اتضح من جدول رقم (• () لنتائج حجم التأثير أن حجم التأثير كبير للمحور الثالثة:

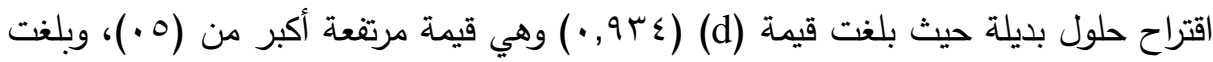

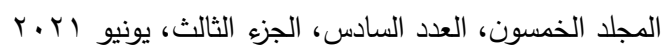


قيمة إيتا (AVT, •). وكان حجم التأثير كبير للدرجة الكلية لمقياس حل المشكلات البيئية

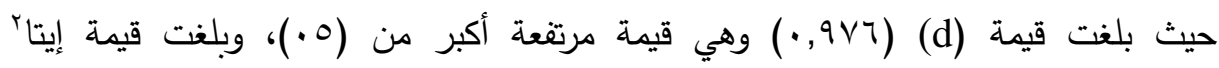
$\cdot(\cdot, 904)$

مما سبق تحقق صحة الفرض الثاني: يوجد فرق دال إحصائيًا بين متوسطي درجات

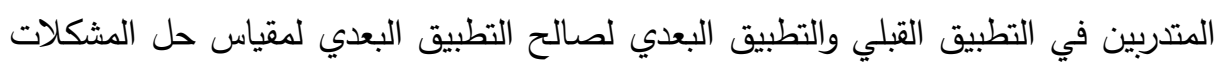

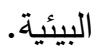
تفسير النتائج: أثبت التطبيق الميداني ما يلي: • وجود فرق دال إحصائيًا بين متوسطي درجات المتدربين في التطبيق القبلي والتطبيق

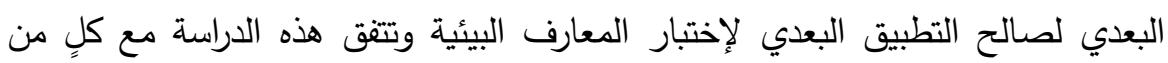

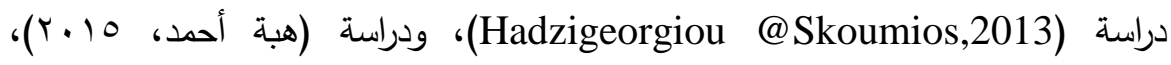

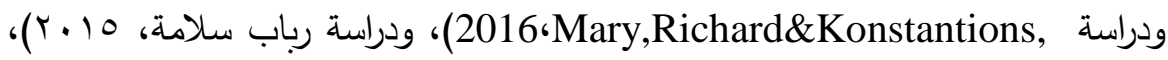

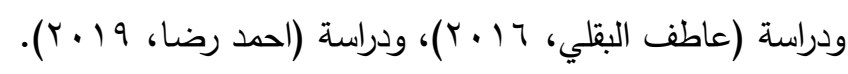
• وجود فرق دال إحصائيًا بين متوسطي درجات المتدربين في التطبيق القبلي والتطبيق البعدي للارجة الكلية لمقياس حل المشكلات البيئية لصالح التطبيق البعدي لمقياس حل

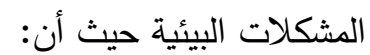

م وجود فرق دال إحصائيًا بين متوسطي درجات المتدربين في التطبيق التبلي والتطبيق

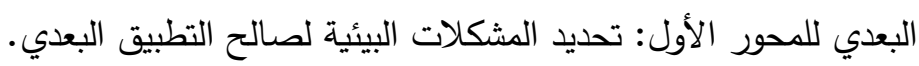

م وجود فرق دال إحصائيًا بين متوسطي درجات المتدربين في التطبيق التبلي والتطبيق البعدي للمحور الثاني: جمع وتتظيم المعلومات لصالح التطبيق البعدي. م وجود فرق دال إحصائيًا بين متوسطي درجات المتدربين في التطبيق التبلي والتطبيق

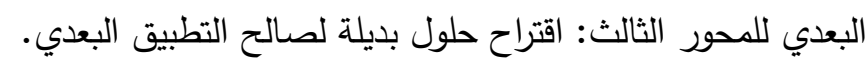

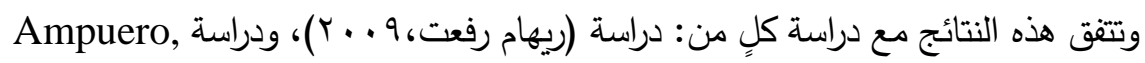

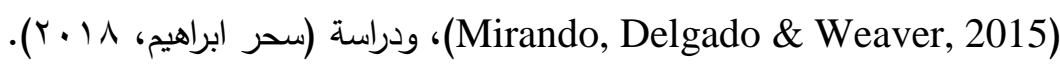
286

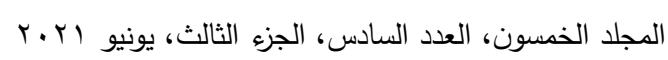

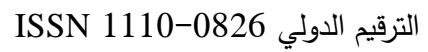


قد يرجع فاعلية البرنامج التدريبي في تتمية المعارف ومهارت حل المشكلات البيئية إلى فلى

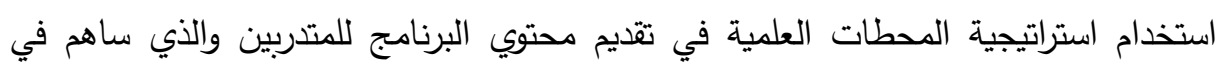
تتمية المعارف ومهارات حل المشكلات البيئية تجاه قضايا (إهدار الموارد البيئية، التلوث

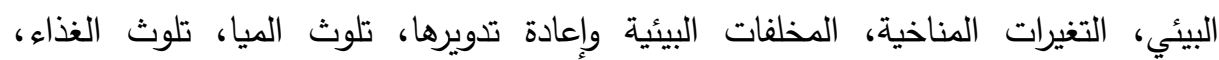

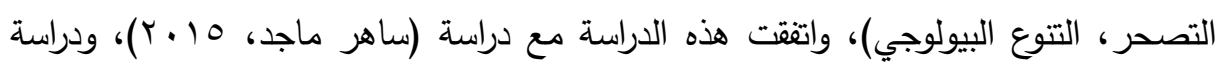

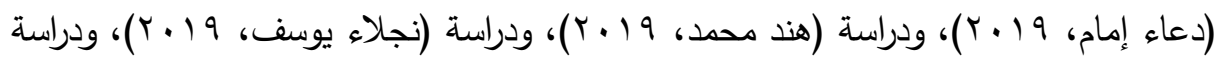

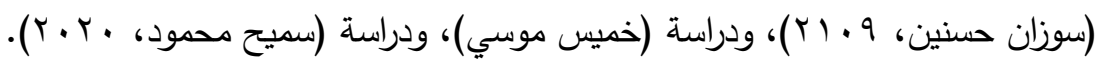

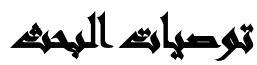

في ضوه ما توصل اليه البحث من نتائج يمكن تقديم التوصيات التالية: • تضمين البرنامج التدريبي لتتمية المعارف ومهارات حل المشكلات البيئية في الخطة لئل التدريبية للعاملين بالجهاز الاداري للدولة.

• الإهتمام بالمعارف ومهارات حل المشكلات البيئية في البرامج التدريبية المقدمة للعاملين بالجهاز الاداري للدولة. • استخدام اختبار المعارف البيئية لقياس مستوى المعارف البيئية للى العاملين بالجهاز الإداري للدولة. • استخدام مقياس مهارات حل المشكلات البيئية لقياس مستوى مهارات حل المشكلات البيئية لاى العاملين بالجهاز الاداري للدولة. • إعداد دليل ارشادي للمدربين للتدريب وفق استراتيجية المحطات العلمية. في ضوء ما توصل اليه البحث من نتائج يقترح إجراء الدراسات التالية:

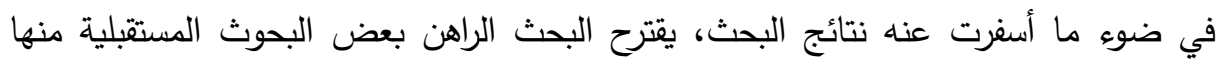
التالي:

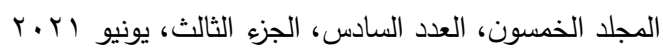

$$
\begin{aligned}
& \text { الترقيم الدولي 0826-0 التيول }
\end{aligned}
$$


• برنامج تدريبي قائم على استراتيجية المحطات العلمية لتتمية المواطنة لدى العاملين

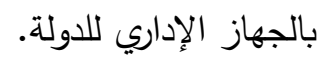

•برنامج تدريبي قائم على استراتيجية المحطات العلمية لتمية المسؤولية البيئية لاى العاملين بالجهاز الاداري للدولة.

دراسة تقويمية للبرامج التدريبية المقدمة للعاملين بالجهاز الاداري للدولة في ضوه المعارف ومهارات حل المشكلات البيئية.

\section{المرالمج}

إبراهيم عصدت مطاوع (1990): التربية البيئية، دار النشر، دراسة نظرية تطبيقية الاسكندرية، دار المعرفة الجامعية، (1) (1)

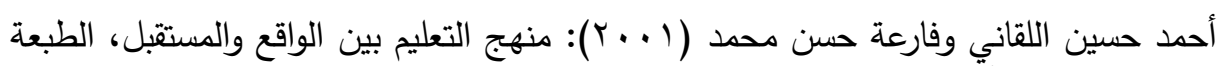

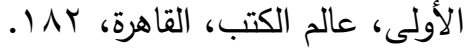

أحمد رضا على فرج (9 ( ب): استخدام مدخل المشروعات لتتمية المعارف والمهارات البيئية

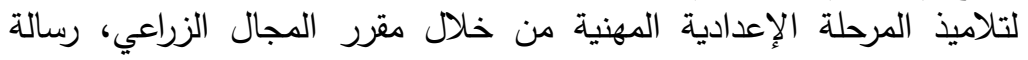
ماجستير منشورة، معهد الدراسات والبحوث البئئية البئة

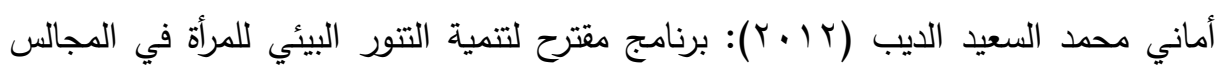
المحلية بالقري، رسالة ماجستير منشورة، معهد البحوث والدراسات البيئية، جامعة عين شمس. بالقري.

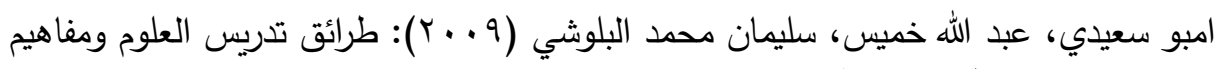

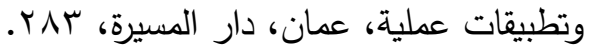

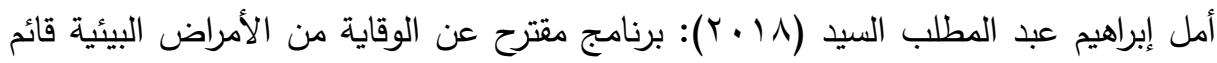

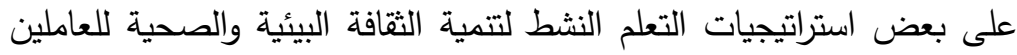

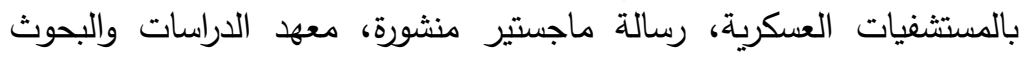

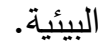




$$
\begin{aligned}
& \text { مجلة العلوم البيئية } \\
& \text { معهد الدراسات والبحوث البيئية - جامعة عين شمس به } \\
& \text { غادة محمد رشاد وآخرون }
\end{aligned}
$$

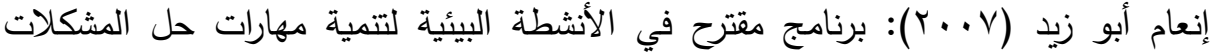
البيئية، رسالة ماجيستير غير منشورة، كلية التربية، جامعة عين شمس.

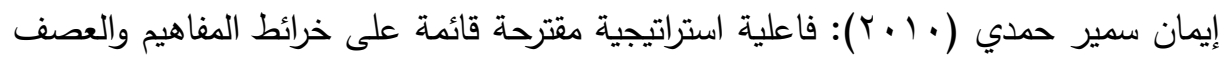

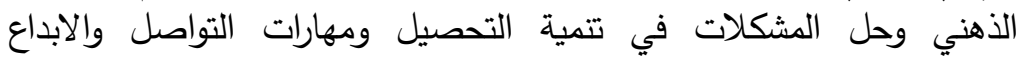
الرياضي لدى تلاميذ المرحلة الإعدادية، رسالة دكتوراه، كلية البنات، جامعة التية عين شمس.

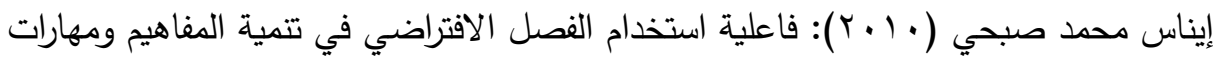

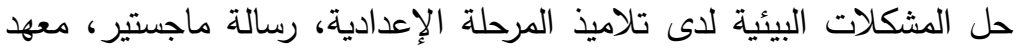

$$
\text { الدراسات والبحوث البيئية، جامعة عين شمس. }
$$

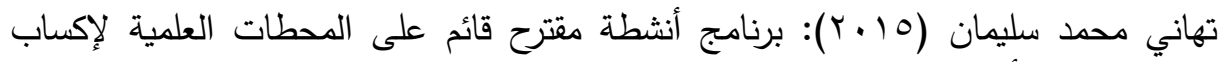

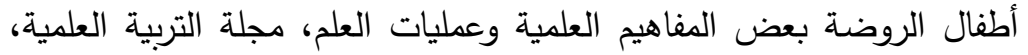

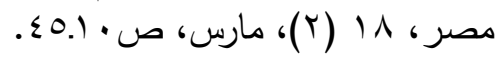

حمدى طلعت خليفة فداوي (ع ( ب): برنامج مقترح لتتمية المسؤولية البيئية بأبعاد التتمية

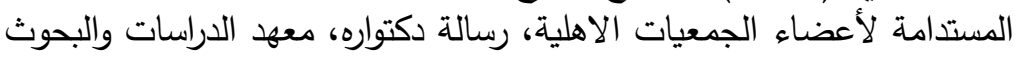

$$
\text { البيئية، جامعة عين شمس. }
$$

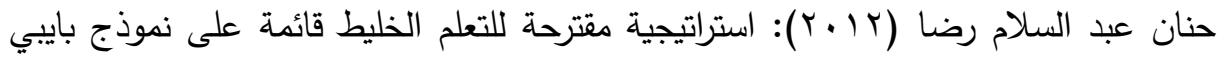

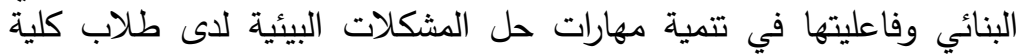

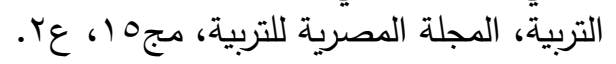

خميس موسى خميس نجم (9 ( †): أثر استراتيجية المحطات العلمية في اكتساب المفاهيم

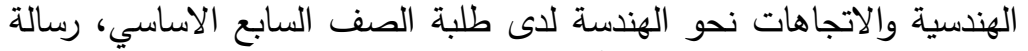

$$
\text { ماجستير ، كلية العلوم التربية، الأردن. }
$$

دعاء إمام غباشي الفقي (19 ( ب): توظيف استراتيجية المحطات التعليمية في تتمية المفاهيم

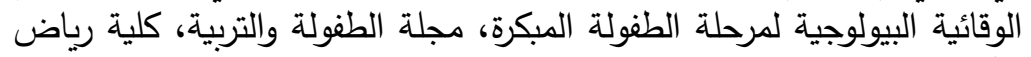

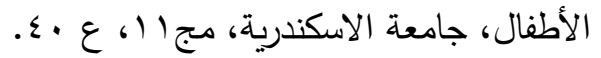

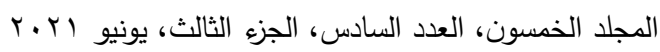

$$
\begin{aligned}
& \text { الترقيم الدولي 0826- التئي }
\end{aligned}
$$


رباب محمود سلامة (7 ( ب): فاعلية استخدام استراتيجية التعليم التوليدي لتعديل الدفاهيم

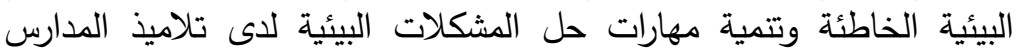

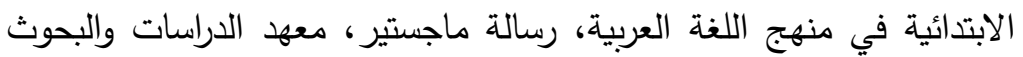
البيئية، جامعة عين شمس.

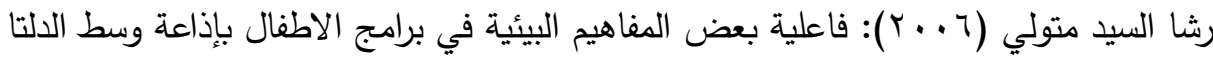

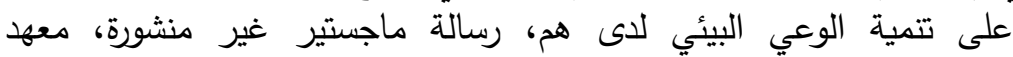

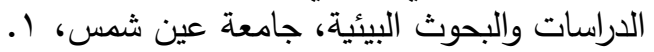

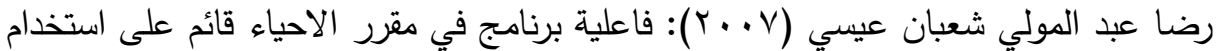

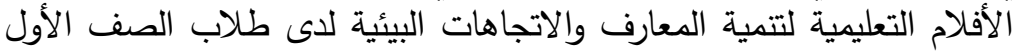
الثانوي، رسالة ماجيستير غير منشورة، معهد الدراسات والبحوث لإنة البيئية جامعة البهات عين شمس.

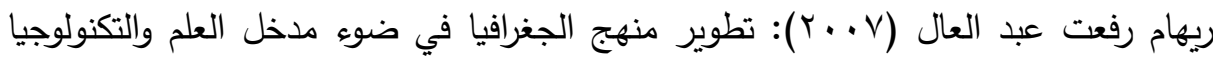

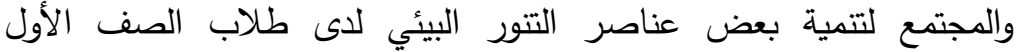
الثانوي، رسالة دكتوراه، معهد الدراسات والبحوث البيئية، جامعة عين شمس.

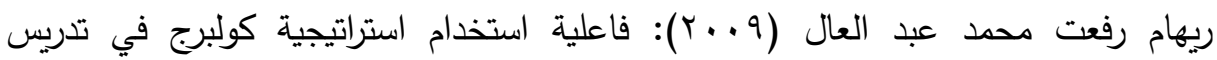

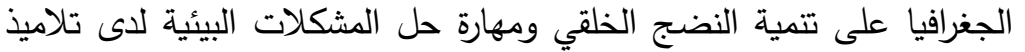

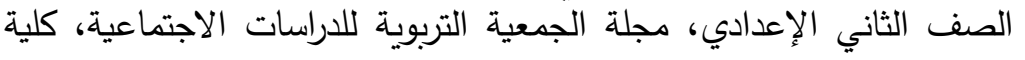

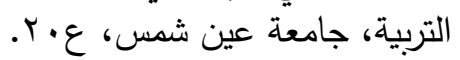

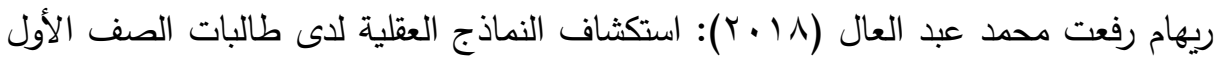

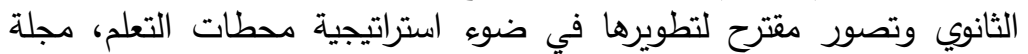

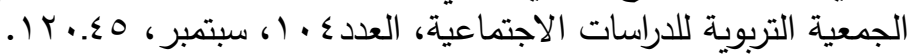

زينب جمال عيد قشطة (1) ( ب): أثر توظيف استراتيجي المحطات العلمية والالعاب التعليمية

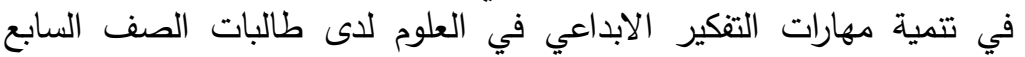

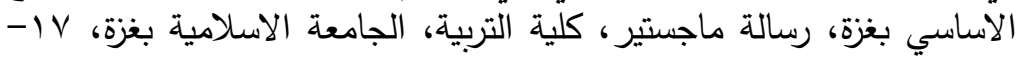


ساهر ماجد شهدة فياض (10) ب ب أثر توظيف استراتيجيتي المحطات العلمية والخرائط

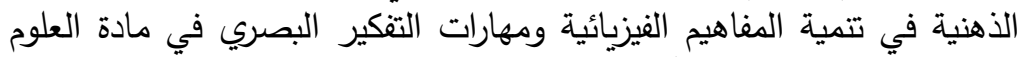

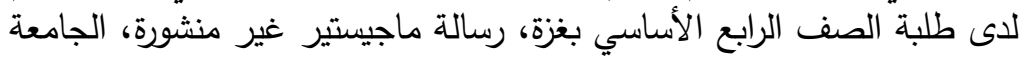
الإسلامية كلية التربية، غزبة.

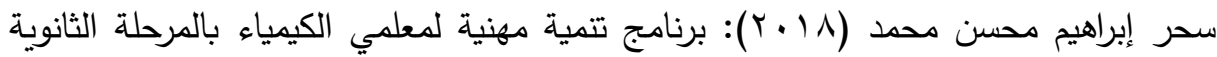

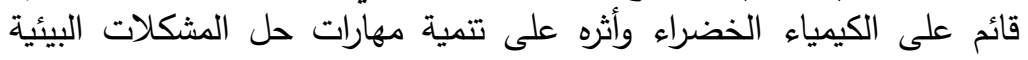

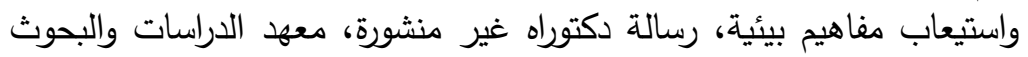
البيئية، جامعة عين شمس.

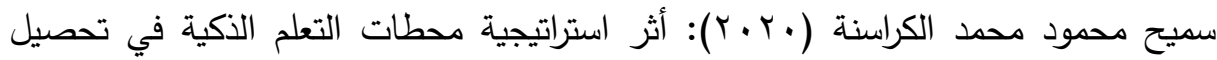

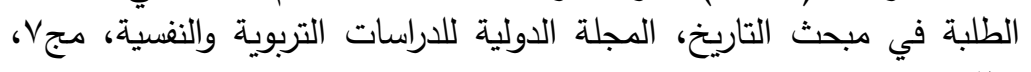
re

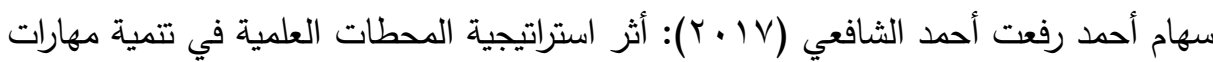

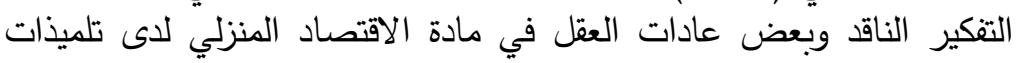

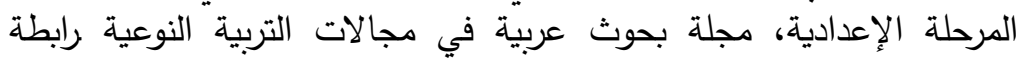

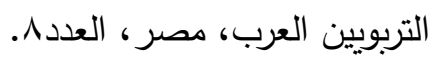

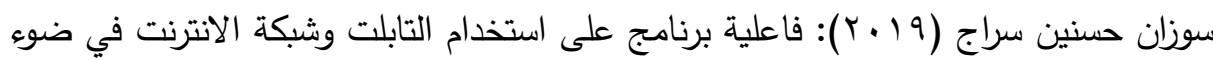

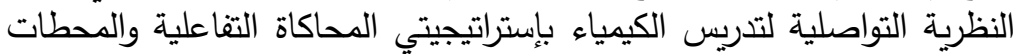

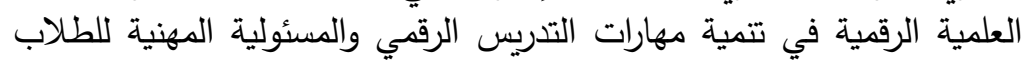

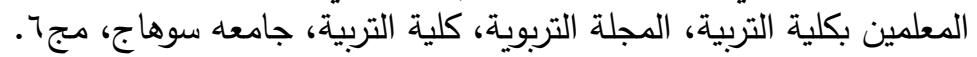

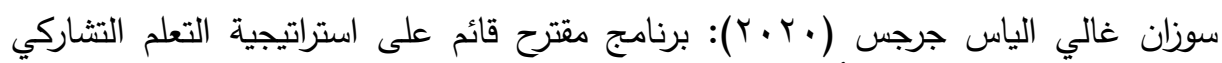

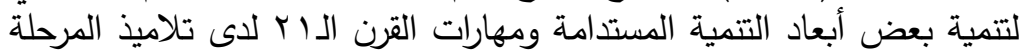

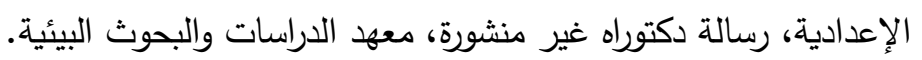

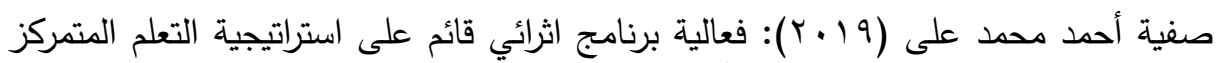

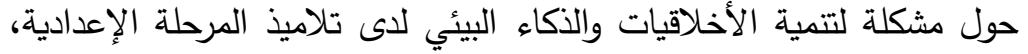

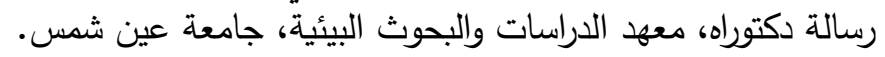




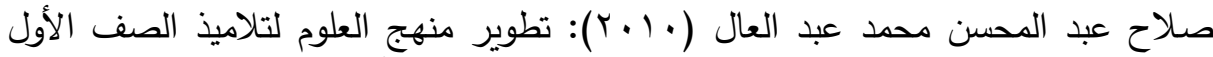

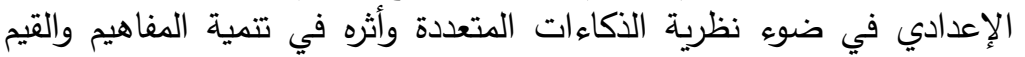

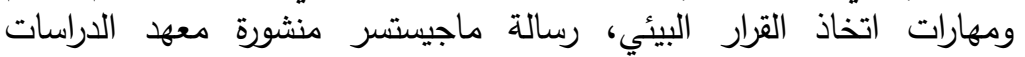

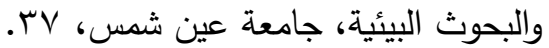

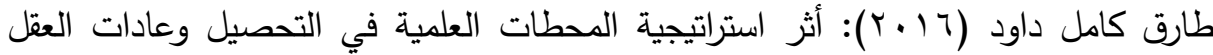

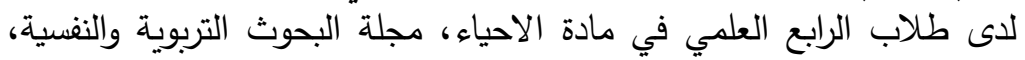

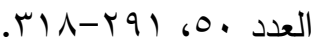

طلعت عبد الرحيم أحمد عبد المطلب (9 1 ب): فاعلية برنامج كورت لتتمية التتور البيئي ومهارات التنكير لاى مديري القطاعات الحكومية، رسالة ماجستير منشورة، التهاتية معهد الدراسات والبحوث البيئية.

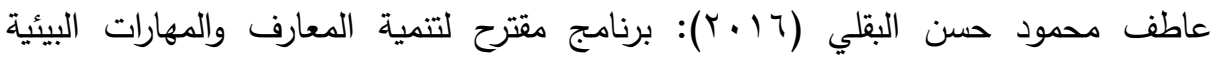
المرتبطة بالتصنيع الغذائي لاى طلاب الئ المدارس الزراعية، رسالة ماجيستير

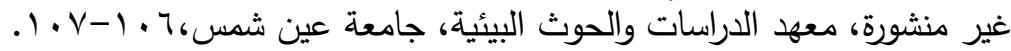

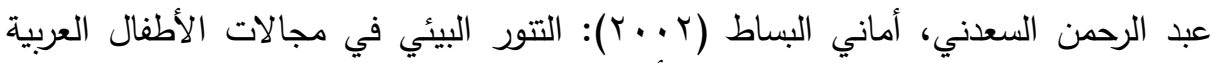

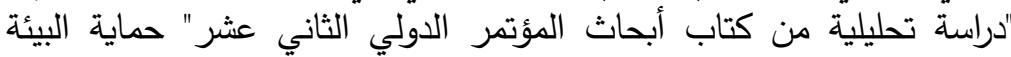

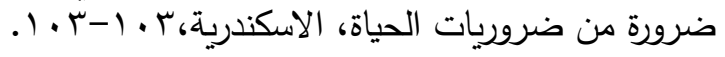

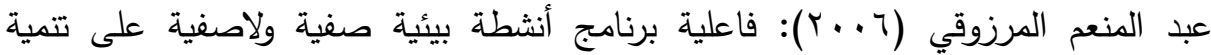

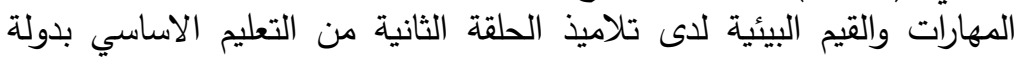

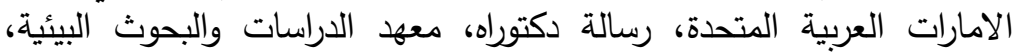
جامعة عين شمس، . - 1. 1.

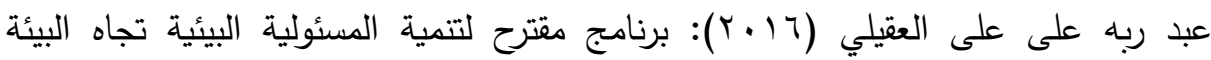

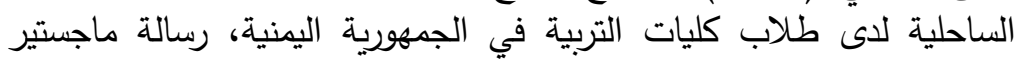

$$
\text { منشورة، معهد الدراسات والبحوث البيئية. }
$$

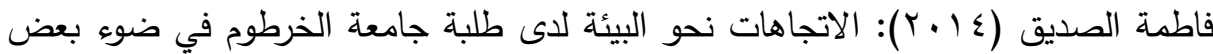

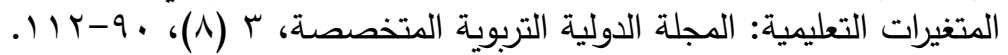

فاطمة بنت عبد الله على الحمادية (1 . . ب): المعرفة البيئية لدى معلمي العلوم في سلطنة عمان، رسالة ماجستير، كلية التربية، جامعة اليرموك، الإردن. 
فتحية طويل (r (†): التربية البيئية ودورها في التتمية المستدانة، دراسة ميدانية بمؤسسات

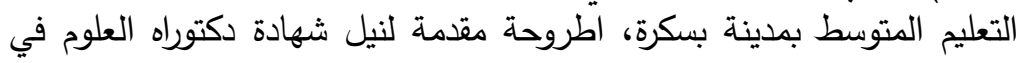

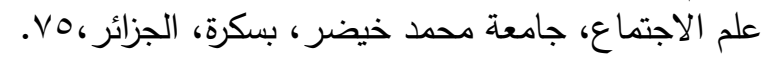

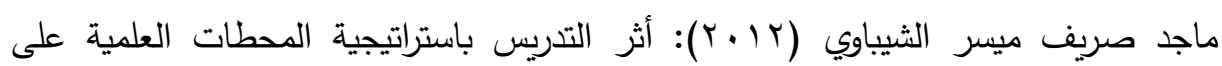

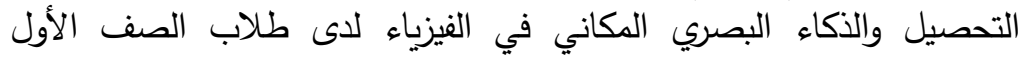
المتوسط، كلية التربية، رسالة ماجيستير غيرير منشورة، جامعة القادسية.

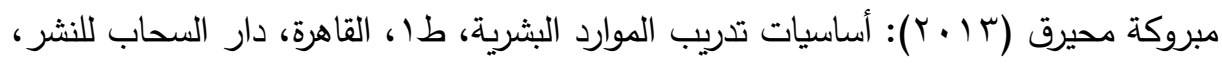
(19 - م

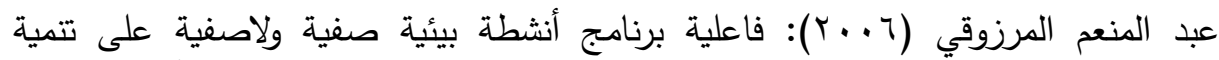

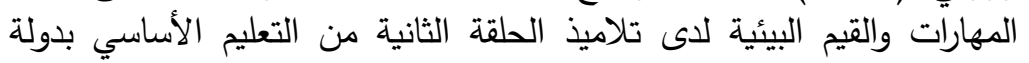

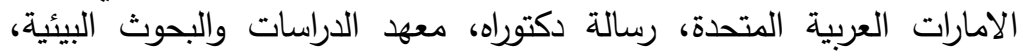

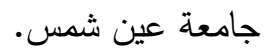

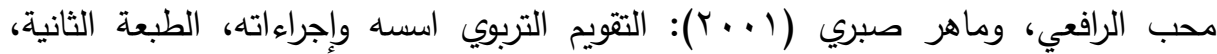

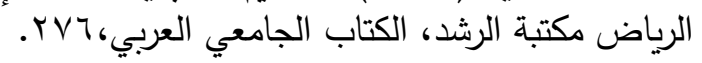

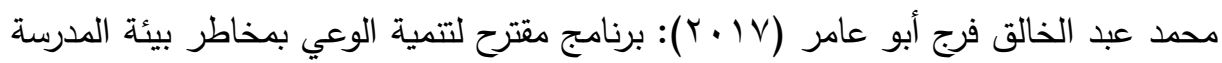

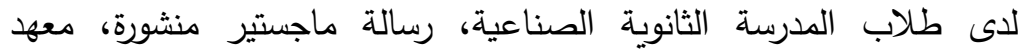

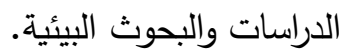

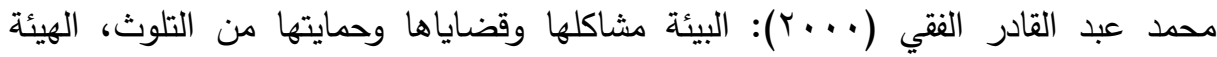

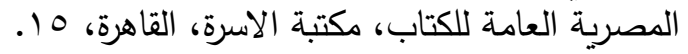

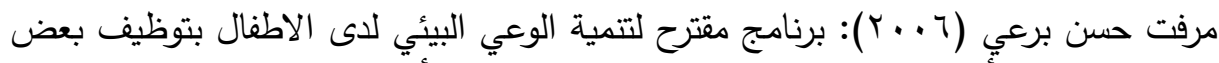

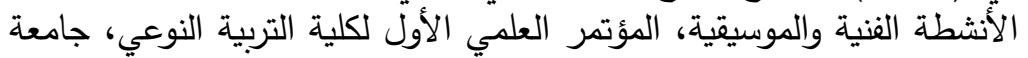

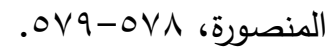

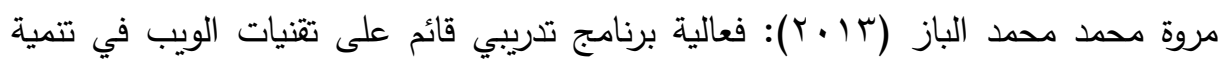

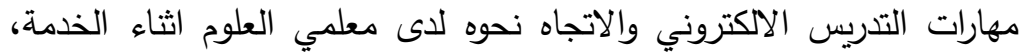

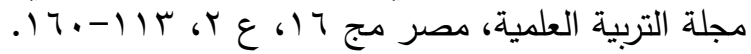

$$
\begin{aligned}
& \text { المجلد الخمسون، العدد الساد، الجزء الثالث، يونيو 1, Y.r. }
\end{aligned}
$$

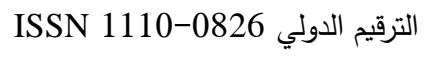




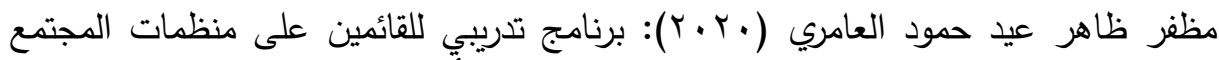

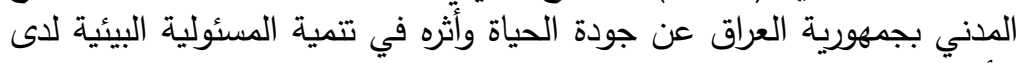

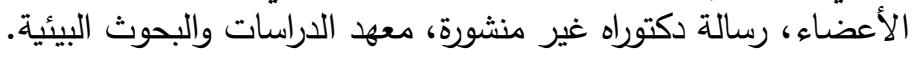

منصور احمد عبد المنعم (Y (Y)): برنامج قائم على مهارات حل المشكلات البيئية في

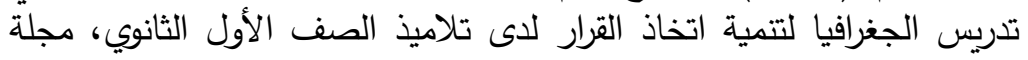

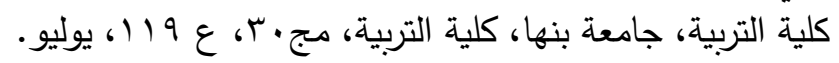

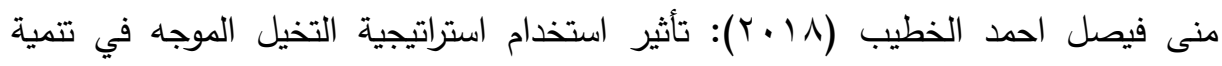
التحصيل ومهارات حل المشكلات البيئية والحس العلمي لاتى طالبية البات كلية

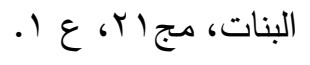

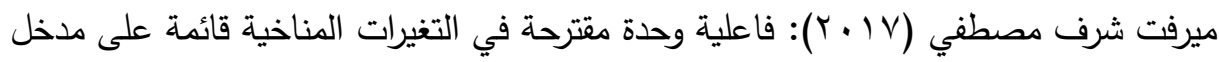

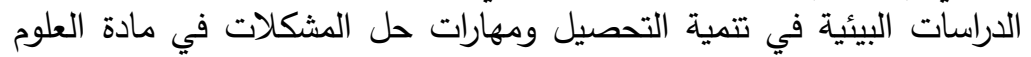

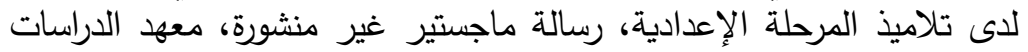
والبحوث البيئية، جامعة عين شمس.

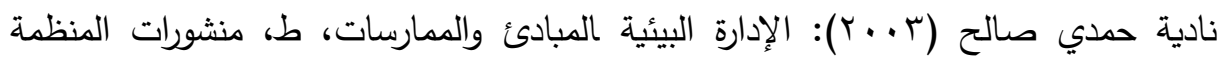

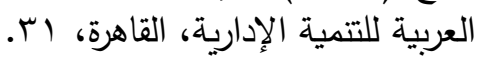

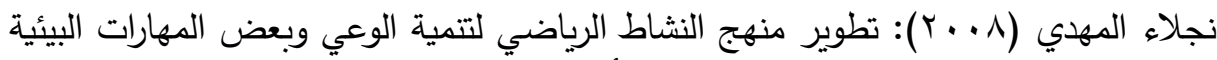

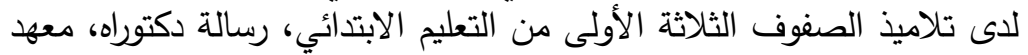

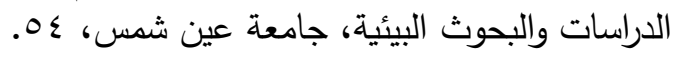

نجلاء يوسف حواس (9 (ب): فاعلية استراتيجية المحطات التعليمية في تدريس الوحدة

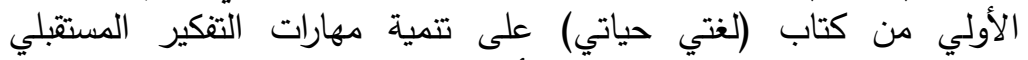
والتحصيل المعرفي لتلاميذ الصف الأفئي الأول الإعدادي، مجلة كلية التربية، كلية

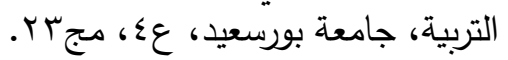

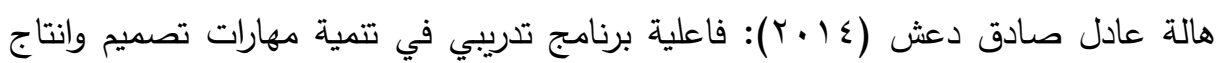

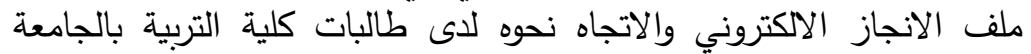

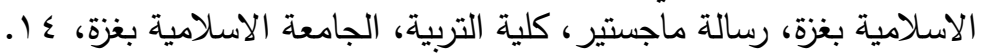




$$
\begin{aligned}
& \text { مجلة العلوم البيئية } \\
& \text { معهد الدراسات والبحوث البيئية - جامعة عين شمس به } \\
& \text { غادة محمد رشاد وآخرون }
\end{aligned}
$$

هبة أحمد السيد أحمد (10 ب): تقويم دور بعض القنوات الفضائية الزراعية في تتمية

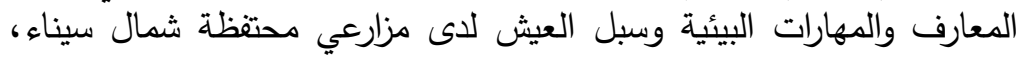

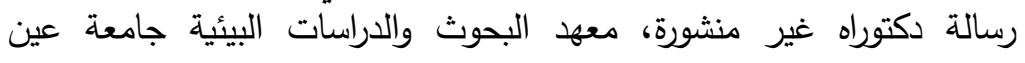
شمس.

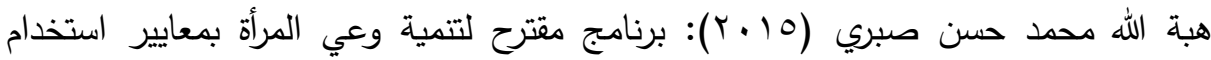
النباتات المعروفة بالطبيعة، رسالة ماجستير منشورة، معهد الدراسات والبحوث البرث البيئية.

هند محمد حسين بايطين (9 (ب)): فاعلية استراتيجية المحطات العلمية في تدريس العلوم

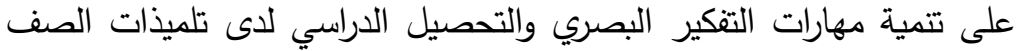

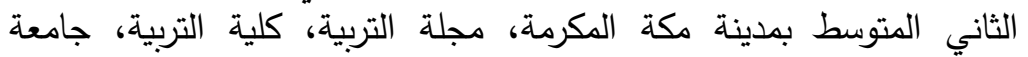

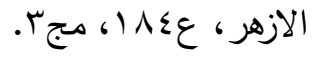

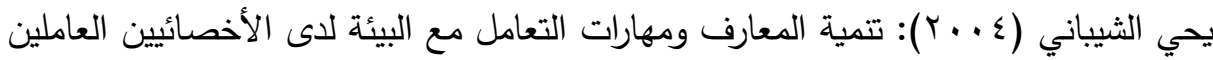

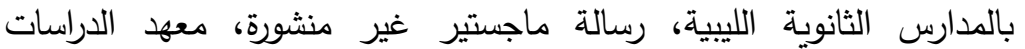

$$
\text { والبحوث البيئية، جامعة عين شمس. }
$$

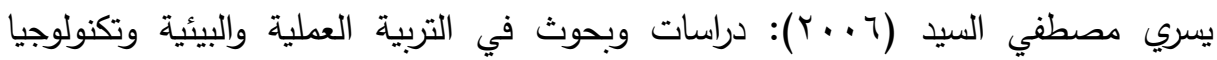

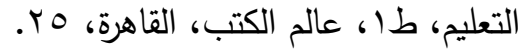

يوسف محمود قطامي (ع ( ب Y): المرجع في تعليم التفكير ، ط (، عمان، دار المسيرة للنشر

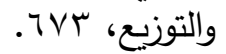

Ampuero, D.; Mirando, C., Delgado, L., Goyen, S. and Weaver, S. (2015): Empathy and critical thinking; primary student solving local environmental problem. Through out door learning. Journal of Adventure education \& out door learning ,15 (1), 64-78.

Chambers, D. (2013): Station Learning; Does it clarify Misconception change and increase Academic. A. Master, s Research Project Presented, ohio university, 15.

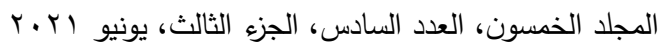

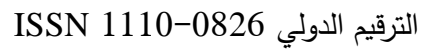




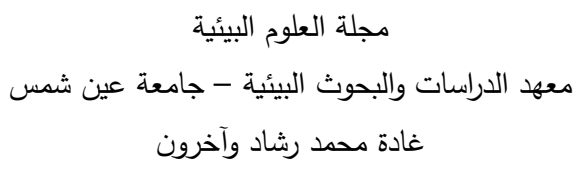

Fatma Sadik, Semra Sadik, (2013): A study on Environmental Knowledge and attitudes of teacher candidates cukurova university faculty of education, turkey. procedia-social and behavioral science 116 (2014).

Hadzigeorgiou Y.@Skoumios M. (2013): The Development of environment awareness through school science, problems and possibilities, International Journal of Environmental @ Science Education, 8, p405-426.

Hye-Eun Chu (2007): International Journal of science educations, p 731-746

Jacobi P. (2005): Environmental Education; the challenge of constructing a critical, complex and reflective thinking, Educ. Pesqui vol.31 no.2.

Jones, D. (2007): The station approach; How to teach with limited Resources, science scope,100-101.

Marvin. M. E. (2007): Using learning station in the secondary's. English classroom Journal of Bethehem College, master of education.

Mary, P.; Richard, H. and Konstantions, C. (2016): Environmental Knowledge, pro environmental bahaviour and energy saving in households; an empirical study, www.research gate.net

Nermin Bulunuz and Olga, Jarrett (2010): The effects of hands on learning science station on building American elementary teachers understanding about earth and space science concepts, Journal of mathematics science and technology Education, 6 (2),85-99.

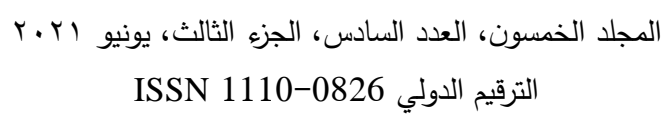




$$
\begin{aligned}
& \text { مجلة العلوم البيئية } \\
& \text { معهد الدراسات والبحوث البيئية - جامعة عين شمس لفس } \\
& \text { غادة محمد شاد وآخرون }
\end{aligned}
$$

Ocak, G. (2010): The effect of learning stations on the level of academic success and retention of elementary school students "The new education review vol(21), No(2), pp (146-156).

Pedaste, M@Sarapuu, T. (2006): The factor influencing the outcome of solving story problem in web. Based Learning environmental, interactive Learning Environments, v142, p153-176

William Stapp @Darothy Cox, (1975): Environmental Education Activities Manual Volume, Concerning Space Ship Esth.

Xingcun, L.U. (2004): The role of Biology in Environmental Education Chinse, Education \& Society, v32, n4, P68_70.

$$
\begin{aligned}
& \text { المجلد الخمسون، العدد الساد، الجزء الثالث، يونيو 1, Y.r. } \\
& \text { الترقيم الدولي 0826- ISSN 1110 الكني }
\end{aligned}
$$




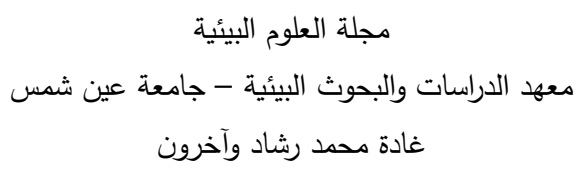

\title{
A TRAINING PROGRAM BASED ON THE STRATEGY OF SCIENTIFIC STATIONS FOR DEVELOPING KNOWLEDGE AND SKILLS FOR SOLVING ENVIRONMENTAL PROBLEMS OF EMPLOYEES OF THE CENTRAL AGENCY FOR ORGANIZATION AND ADMINISTRATOR
}

\author{
Ghada M. Rashad ${ }^{(1)}$; Reham R. Abdel Aal ${ }^{(2)}$ \\ and Hanan E. Zedan ${ }^{(2)}$
}

1) Post graduate student at Institute of Environmental Studies \& Research, Ain Shams University 2) Institute of Environmental Studies \& Research, Ain Shams University

\begin{abstract}
The current research's purpose is develop knowledge and skills for solving environmental problems by designing a program based on the strategy of scientific stations and measuring its effectiveness. A list of some knowledge and skills for solving environmental problems has been prepared that are suitable for their development among the employees of the Central Agency for Organization and Administrator. Ten training sessions, and an environmental knowledge test consisting of (32) items has been designed, in addition to a scale of environmental problem-solving skills consisting of three axes. The first axis is the axis of defining the environmental problems and consists of (17) items. The second axis is the axis of organizing information and data which consists of (17) items and the third axis is a proposal axis for solutions to problems that consists of (17) items.
\end{abstract}

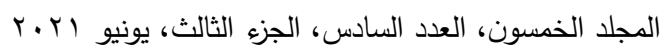

$$
\begin{aligned}
& \text { الترقيم الدولي 0826- ISSN 1110 }
\end{aligned}
$$




$$
\begin{aligned}
& \text { مجلة العلوم البيئية } \\
& \text { معهد الدراسات والبحوث البيئية - جامعة عين شمس لهس } \\
& \text { غادة محمد رشاد وآخرون }
\end{aligned}
$$

A Pre/application of the measurement tools was administered, then the training program was applied to an experimental group consisting of (32) male/female employees from the Central Agency for Organization and Administrator, and then a post-measurement tools were applied.

The results indicate a statistically significant difference exists between the average scores of the experimental group regarding the pre/post application on the Test of Environmental Knowledge, in favor of the post application at (0.01) significance level. There is also a statistically significant difference between the average scores of the experimental group regarding the pre/post application of the scale of environmental problem-solving skills at (0.01) significance level.

The research recommends that the training program should be included in the training plan presented to employees of the state's administrative apparatus.

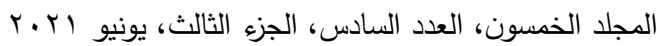

$$
\begin{aligned}
& \text { الترقيم الدولي 0826-0 التئي }
\end{aligned}
$$

